Review

\title{
Current Developments of Carbon Capture Storage and/or Utilization-Looking for Net-Zero Emissions Defined in the Paris Agreement
}

\author{
Maria João Regufe*(D), Ana Pereira (D), Alexandre F. P. Ferreira, Ana Mafalda Ribeiro (D) and Alírio E. Rodrigues \\ LSRE-LCM-Laboratory of Separation and Reaction Engineering-Laboratory of Catalysis and Materials, Associate \\ Laboratory, Faculdade de Engenharia, Universidade do Porto, Rua Dr. Roberto Frias, 4200-465 Porto, Portugal; \\ ajmp@fe.up.pt (A.P.); aferreir@fe.up.pt (A.F.P.F.); apeixoto@fe.up.pt (A.M.R.); arodrig@fe.up.pt (A.E.R.) \\ * Correspondence: mjregufe@fe.up.pt
}

check for updates

Citation: Regufe, M.J.; Pereira, A.; Ferreira, A.F.P.; Ribeiro, A.M.;

Rodrigues, A.E. Current

Developments of Carbon Capture Storage and/or Utilization-Looking for Net-Zero Emissions Defined in the Paris Agreement. Energies 2021, 14, 2406. https://doi.org/10.3390/ en14092406

Academic Editor: Attilio Converti

Received: 22 March 2021

Accepted: 9 April 2021

Published: 23 April 2021

Publisher's Note: MDPI stays neutral with regard to jurisdictional claims in published maps and institutional affiliations.

Copyright: (c) 2021 by the authors. Licensee MDPI, Basel, Switzerland. This article is an open access article distributed under the terms and conditions of the Creative Commons Attribution (CC BY) license (https:/ / creativecommons.org/licenses/by/ $4.0 /)$.
Abstract: An essential line of worldwide research towards a sustainable energy future is the materials and processes for carbon dioxide capture and storage. Energy from fossil fuels combustion always generates carbon dioxide, leading to a considerable environmental concern with the values of $\mathrm{CO}_{2}$ produced in the world. The increase in emissions leads to a significant challenge in reducing the quantity of this gas in the atmosphere. Many research areas are involved solving this problem, such as process engineering, materials science, chemistry, waste management, and politics and public engagement. To decrease this problem, green and efficient solutions have been extensively studied, such as Carbon Capture Utilization and Storage (CCUS) processes. In 2015, the Paris Agreement was established, wherein the global temperature increase limit of $1.5^{\circ} \mathrm{C}$ above pre-industrial levels was defined as maximum. To achieve this goal, a global balance between anthropogenic emissions and capture of greenhouse gases in the second half of the 21st century is imperative, i.e., net-zero emissions. Several projects and strategies have been implemented in the existing systems and facilities for greenhouse gas reduction, and new processes have been studied. This review starts with the current data of $\mathrm{CO}_{2}$ emissions to understand the need for drastic reduction. After that, the study reviews the recent progress of CCUS facilities and the implementation of climate-positive solutions, such as Bioenergy with Carbon Capture and Storage and Direct Air Capture. Future changes in industrial processes are also discussed.

Keywords: $\mathrm{CO}_{2}$ emissions; CCS; CCUS; global facilities

\section{Introduction}

Due to the Industrial Revolution, fossil fuels (coal, oil and gas) were unlocked as a new energy resource. Their excessive use has led to several negative impacts such as global climate change [1].

Figure 1 presents the surface air temperature anomalies between 1979 and 2020. For example, comparing with September 2016, September 2019 was the warmest month in the data record, which was $0.57^{\circ} \mathrm{C}$ warmer than the average temperature from 1979-2010 [1]

Natural causes are also responsible for this effect. However, greenhouse gases from human activities including population growth, deforestation, agriculture, urbanization (urban heat islands), and the resulting changes in consumption patterns are responsible for more than $95 \%$ of global warming [2]. The greenhouse contribution in the temperature variation is evident, responsible for about $1^{\circ} \mathrm{C}$, more than other anthropogenic sources and natural variations.

The principal greenhouse gas related to global climate change is carbon dioxide $\left(\mathrm{CO}_{2}\right)$. Other gases, in minor quantities, are also responsible, such as methane $\left(\mathrm{CH}_{4}\right)$, water vapor $\left(\mathrm{H}_{2} \mathrm{O}\right)$, nitrous oxide $\left(\mathrm{N}_{2} \mathrm{O}\right)$ and fluorinated gases (F-gases), specially hydrofluorocar- 
bons (HFCs), perfluorocarbons (PFCs), sulfur hexafluoride $\left(\mathrm{SF}_{6}\right)$, and nitrogen trifluoride $\left(\mathrm{NF}_{3}\right)[3,4]$.

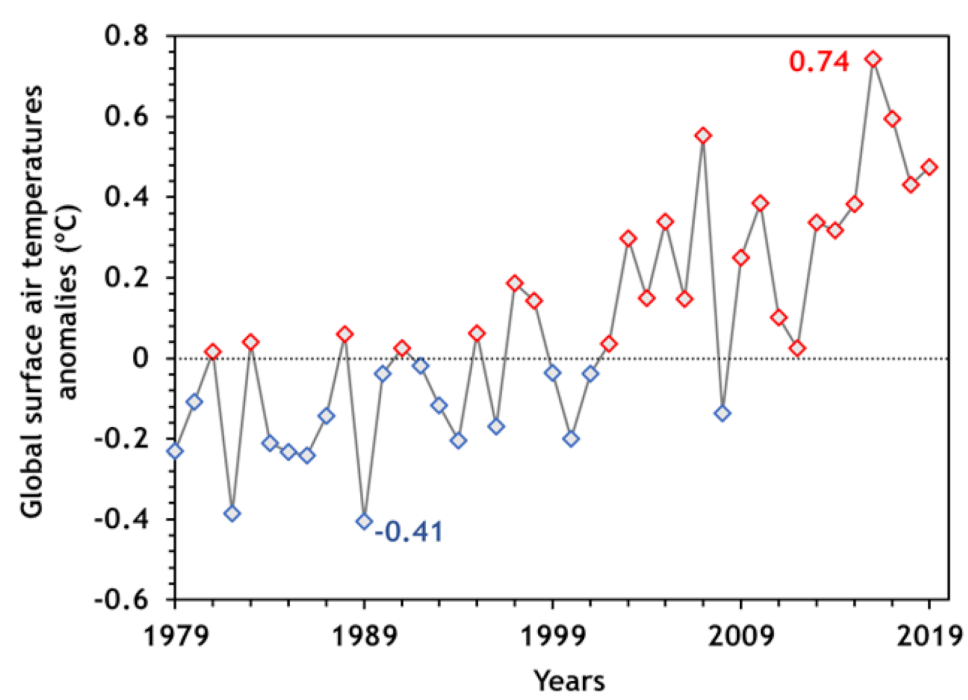

Figure 1. Global mean surface air temperature anomalies in the 1979-2020 period (adapted from Service [1]).

In order to combat climate change and achieve decarbonization, several methods have been studied and implemented: a massive development of clean energies (renewable energy sources); fossil fuel consumption reduction by switching to lower-carbon alternatives, e.g., coal to gas; energy efficiency increase in industrial applications and the power sector, particularly in technologies used to convert fossil fuels into energy; carbon capture and utilization/storage techniques [2,5-7]. The employment of all of the options mentioned above will be required because $\mathrm{CO}_{2}$ emission abatement became a global priority. However, at the current state of development, the levels of risks and the costs, non-fossil fuel energy alternatives cannot meet our need for energy fed by fossil fuels. Additionally, any quick change to non-fossil energy sources, even if this action was possible, would result in large disruptions to the existing energy supply infrastructure with substantial consequences to the global economy [8].

In the Paris Agreement, 196 parties decided to establish a long-term goal to keep the worldwide average temperature increase below $2{ }^{\circ} \mathrm{C}$ above pre-industrial levels and limit the increase to $1.5^{\circ} \mathrm{C}$, since this would significantly reduce the risks and effects of climate change [9-11]. Consequently, to obtain a sustainable low carbon future, global $\mathrm{CO}_{2}$ levels should be drastically reduced by promoting the actions and investments needed. This limitation in the worldwide temperature implies immediate and decisive actions on climate change to avoid some of the worst climate impacts and reduce the chances of extreme weather occurrences around the world.

Thus, to meet mid to long-term $\mathrm{CO}_{2}$ emissions targets, cost-effective $\mathrm{CO}_{2}$ capture from fossil fuel use and subsequent sequestration options need to be evaluated, as well as the utilization of (captured) carbon dioxide as a feedstock for new products. Figure 2 shows the $\mathrm{CO}_{2}$ life-cycle considering two pathways: carbon capture and storage (CCS) and carbon capture and utilization (CCU). 


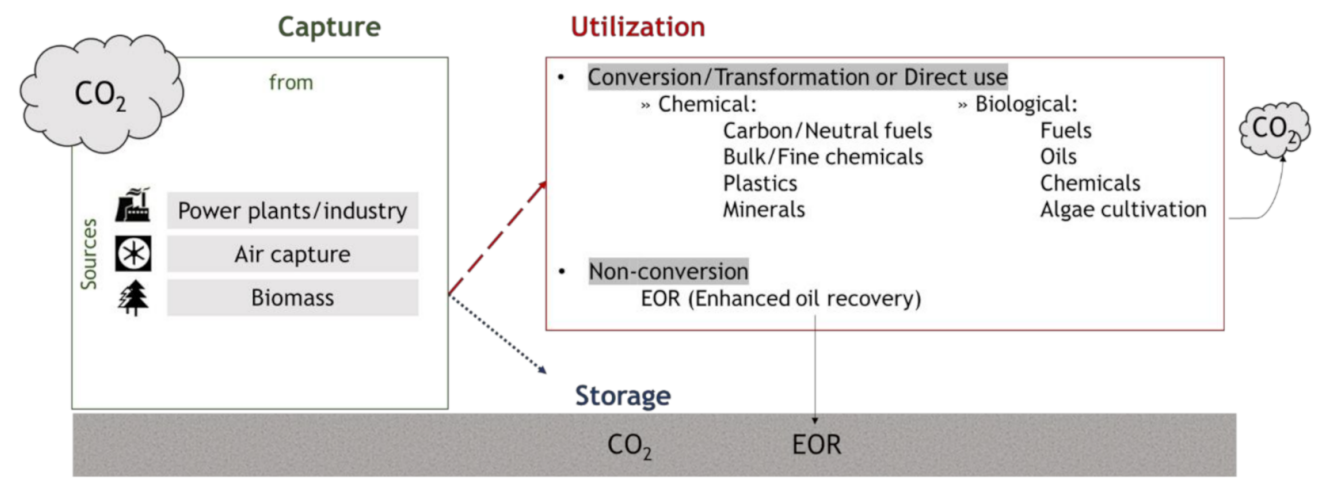

Figure 2. Analysis of life-cycle of $\mathrm{CO}_{2}$ with capture and storage, and capture and utilization from main sources pathways (based on Sekera and Lichtenberger [12] and Bui et al. [13]).

Broadly recognized as having an enormous potential to meet climate change targets, CCS and CCUS appear as solutions to deliver low carbon heat and power, decarbonize the industry, and, more recently, facilitate the net removal of $\mathrm{CO}_{2}$ from the atmosphere [14].

This article aims to review the overall CCS and CCUS strategies implemented to fulfil the climate change ambition established in the Paris Agreement of 2015. The approach to obtain a climate-neutral-an economy with net-zero greenhouse gas emissions-implies large changes in all the economic sectors, as well as energy, transport, industry, and agriculture.

First, the values of actual $\mathrm{CO}_{2}$ emissions are presented, and it is analyzed the impact of COVID-19 in the first quarter of 2020. After that, Carbon Capture and Storage and Carbon Capture, Utilization, and Storage strategies to combat $\mathrm{CO}_{2}$ emissions are described. $\mathrm{CO}_{2}$ capture technologies, classified into three groups, precombustion, oxy-fuel and postcombustion systems, are presented as well as the leading technologies used for $\mathrm{CO}_{2}$ capture. CCUS's current development, focusing on the facilities and projects working in Europe, is presented.

Two commonly used technologies of climate-positive solutions are briefly described, which are bioenergy with carbon capture and storage (BECCS) and direct air capture (DAC). In conclusion, the future of industrial processes, that use fossil fuels as raw materials and release $\mathrm{CO}_{2}$ emissions, is analyzed.

\section{2. $\mathrm{CO}_{2}$ Emissions}

In 2019, global energy-related $\mathrm{CO}_{2}$ emissions reached 33 gigatonnes (Gt), approximately [15]. This resulted mainly from a sharp decline in $\mathrm{CO}_{2}$ emissions from the power sector in advanced economies (Australia, Canada, Chile, European Union, Iceland, Israel, Japan, Korea, Mexico, Norway, New Zealand, Switzerland, Turkey, and United States.), because of the expanding role of renewable sources (mainly wind and solar photovoltaic systems), fuel switching from coal to natural gas, and higher nuclear power output. However, the total emissions, in the rest of the world, increased.

Figure 3 shows the gigatonnes of $\mathrm{CO}_{2}$ emitted by developed countries, the rest of the world, and total emissions from 1990 until 2019 [16].

Figure 4 shows the global greenhouse gas emissions (\%) by sector in 2020 [16]. The economic sector which had the highest share of carbon dioxide emissions from fossil fuels and cement was the power sector. With a $44 \%$ of emissions, this was more than the combined share of both industry and surface transport. These three sectors of the economy make up the majority of the world's $\mathrm{CO}_{2}$ emissions.

Covid-19 had an enormous impact on energy demand and, therefore, on $\mathrm{CO}_{2}$ emissions. The drastic curtailment of global economic activity and mobility during the first quarter of 2020 pushed down global energy demand by about $3.8 \%$ compared with the first quarter of 2019 [15]. $\mathrm{CO}_{2}$ emissions were about 5\% lower in Q1 2020 than in Q1 2019, almost twice as large as all previous declines since the end of World War II. By sectors, emissions from coal, oil, and natural gas declined about $8,4.5$, and $2.3 \%$, respectively. By 
regions, a considerable decrease of $\mathrm{CO}_{2}$ emissions was observed: $-8 \%$ in China, $-8 \%$ in the European Union (EU), and $-9 \%$ in the United States [15]. However, this decline was punctual; it will not be enough to resolve climate change problems.

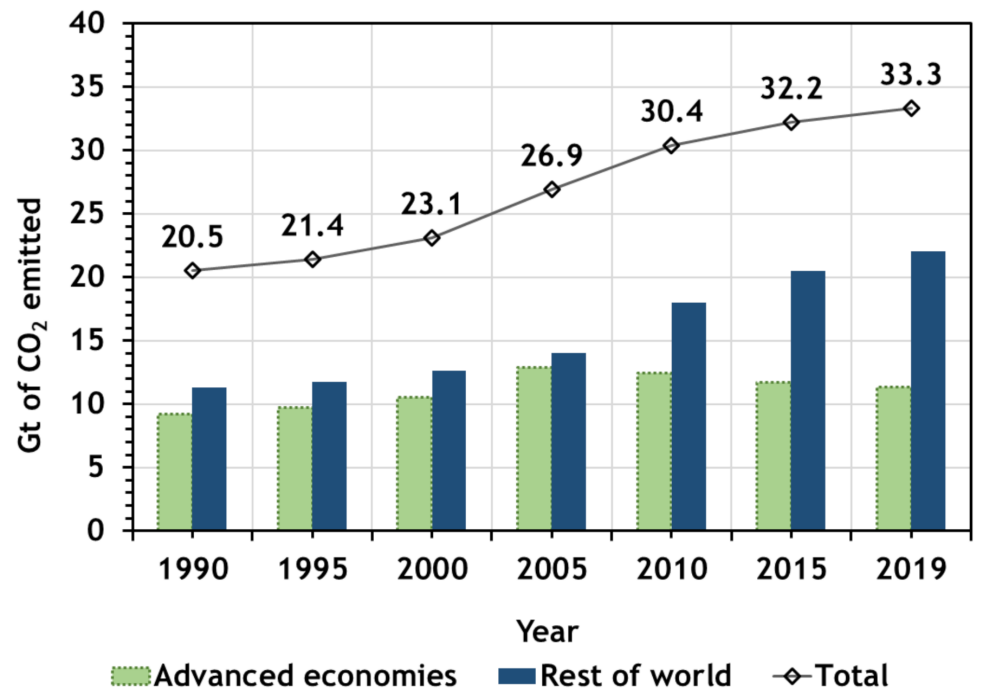

Figure 3. $\mathrm{CO}_{2}$ emissions by countries for a period from 1990 until 2019 (adapted from Agency [16]).

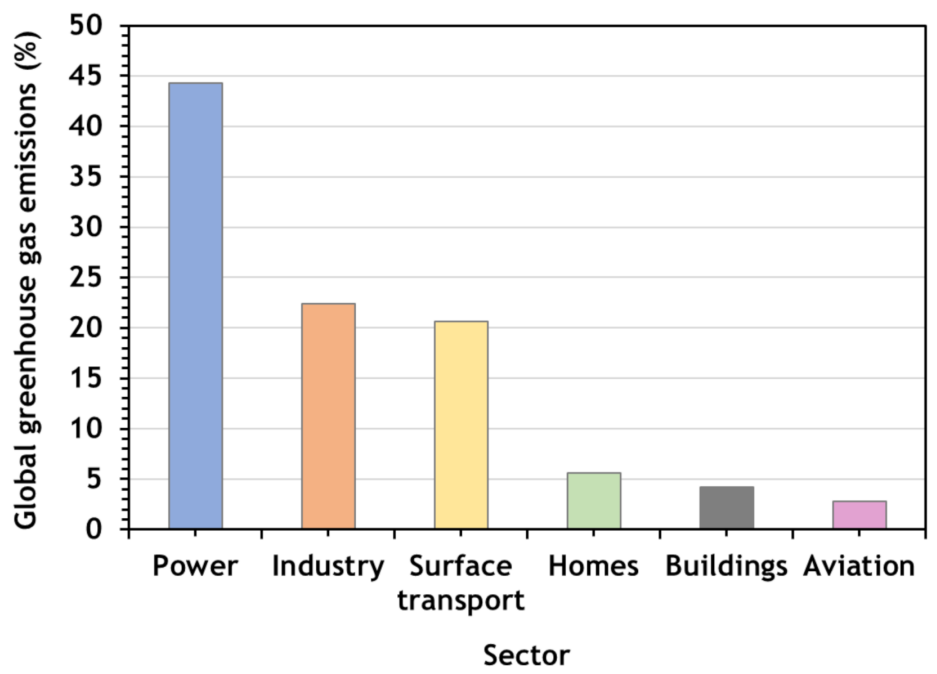

Figure 4. Global greenhouse gas emissions by sector in 2020 (adapted from Tiseo [17]).

In April 2020, McKinsey Global Institute published an overview of several scenarios of projected global $\mathrm{CO}_{2}$ emissions that helps to understand the future. Climate Action Tracker [18] also provide these data. The scenarios are shown in Figure 5, where global $\mathrm{CO}_{2}$ emissions in each scenario are projected. All pathways include energy-related emission, industry-process emissions (e.g., from cement production), emissions from deforestation and waste, and negative emissions (e.g., from reforestation and carbon-removal technologies such as bioenergy with carbon capture and storage, and direct air carbon capture and storage). Emissions from biotic feedbacks (e.g., from permafrost thawing, wildfires) were not considered. The red lines represent warming projections if policies are not applied: the lower bound is a "continued growth" pathway based on the IEA's World Energy Outlook 2019 current policies scenario; the higher bound is based on IPCC's Representative Concentration Pathway 8.5 [19]. It is possible to observe the need for immediate reduction of GHG emissions. 


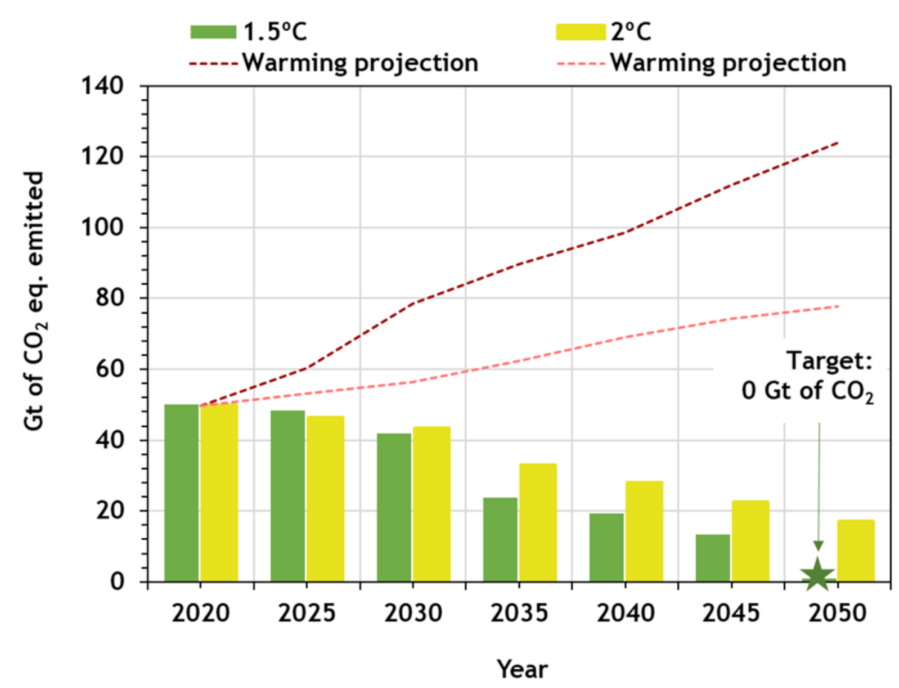

Figure 5. Projected global $\mathrm{CO}_{2}$ emissions per scenario (adapted from Climate Action Tracker [18]).

According to this study, if no changes are applied, the continued growth will lead to about $120 \mathrm{Gt}$ equivalent of $\mathrm{CO}_{2}$ emitted per year in 2050 . However, to achieve the $1.5^{\circ} \mathrm{C}$ pathway of the Paris Agreement, the $\mathrm{CO}_{2}$ emissions should be $0 \mathrm{Gt}$ by then.

\section{Carbon Capture (Utilization) and Storage (CCUS or CCS)}

Basically, carbon capture and storage (CCS) consists of the separation and concentration of $\mathrm{CO}_{2}$ from power generation plants or industrial processes, its pressurization and transportation, via ship or pipeline, to specific locations where it should be permanently stored deep underground, in geological formations (depleted oil or gas reservoirs or deep saline aquifers) $[20,21]$. This technology has been identified as a priority, being a critical emissions reduction technology that can be applied across the energy system, expecting to play an essential role in meeting the global warming targets [22-24].

CCS is often used interchangeably with the term Carbon Capture, Utilization, and Storage (CCUS). The difference between the two terms presented is the 'utilization' word, which refers to the use of carbon for other applications. CCUS can contribute to almost one-fifth of the emissions reductions needed across the industry sector. CCUS will play a key role in reducing $\mathrm{CO}_{2}$ emissions from fossil-fuel-based power generation and is the only option available to reduce direct emissions from other industrial point sources significantly [25]. It was estimated that the use of CCUS would address up to $32 \%$ of global $\mathrm{CO}_{2}$ emissions reduction by 2050 [26]. More than $28 \mathrm{Gt}$ of $\mathrm{CO}_{2}$ could be captured from industrial processes until 2060, the majority of it from the cement, steel, and chemical subsectors [27].

CCS and CCUS technologies are developed slowly, mainly as a result of high costs and unsupportive policy and regulatory frameworks in many countries [28].

The economic penalty of the capture is the crucial obstacle to CCS/CCUS implementation. The efficiency of the $\mathrm{CO}_{2}$ capture must be increased in the capture step of the processes, as it is estimated that the capture step is responsible for $60 \%$ to $80 \%$ of the overall CCS/CCUS economic penalty $[8,20]$. The capture part of the process represents the main promise for cost reduction and focuses on most of the research efforts. CCS or CCUS is far from the ideal solution because it does not directly use green fuels. Still, it is the only technology capable of maintaining the utilization of the existing power plants.

In these types of processes, $\mathrm{CO}_{2}$ capture technologies can be classified into three groups: pre-combustion systems, post-combustion systems, and oxy-fuel or oxy-combustion processes. The first and second systems depend on whether carbon dioxide is removed before or after fuel is burned. In the third, pure oxygen rather than air is used for combustion [3]. Figure 6 shows a brief scheme of methods for carbon capture. 


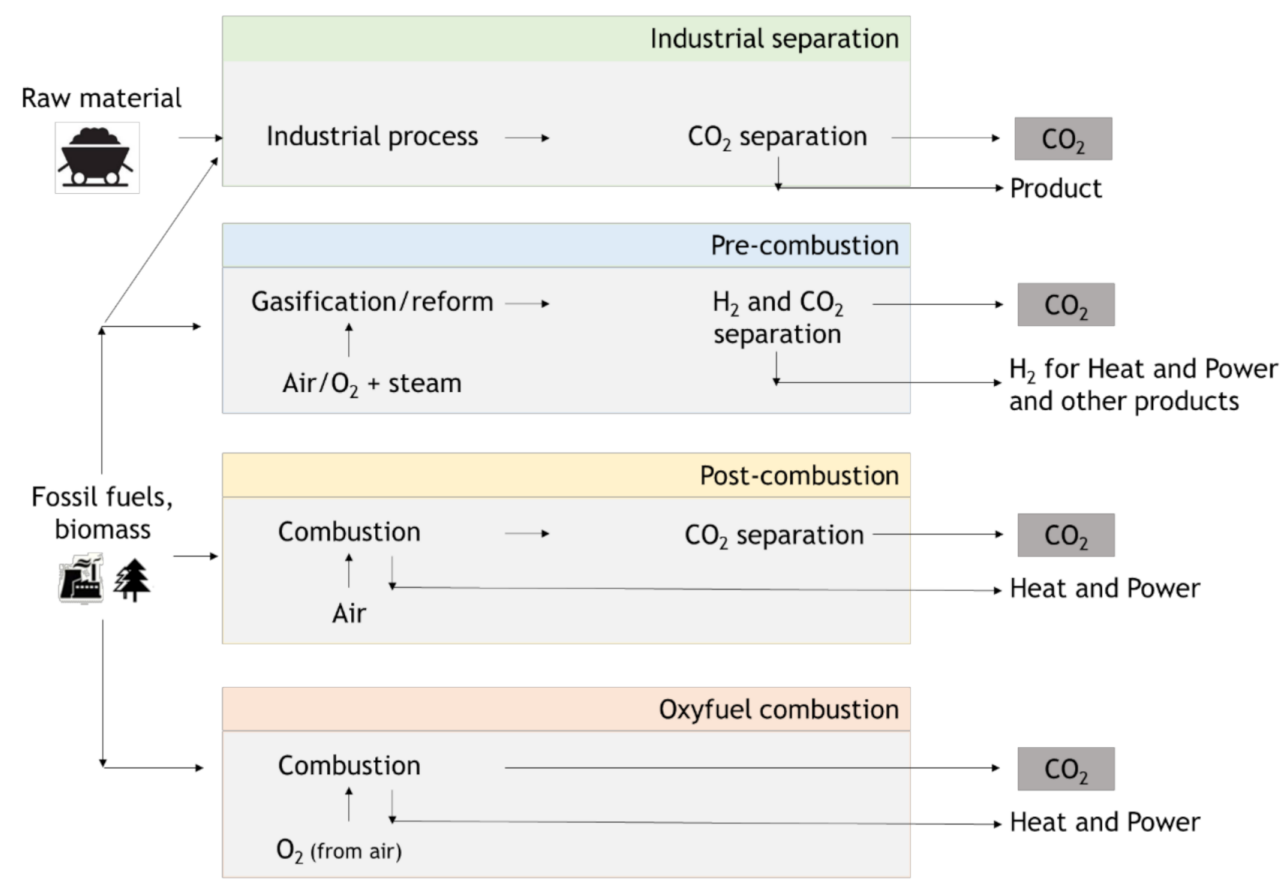

Figure 6. Scheme of methods for carbon capture (adapted from IPCC [29]).

In the production processes, namely in activities related to $\mathrm{CO}_{2}$ and other harmful greenhouse gases, even in coal power plants, it is important to reduce the emissions. For that, energy production changes as technology advances. Energy companies and industries use several technologies. This way, Industry 4.0 and the external environment force the energy companies to constantly adjust goals [2,30]. Oxy-combustion capture is still under development and is not yet commercial. Reduction of NOx, SOx, Hg emissions, and methods of exhaust gas dedusting are also important.

\subsection{Pre-Combustion}

In power plants, in oil, gas, and chemical industries processes, where $\mathrm{CO}_{2}$ is produced, the pre-combustion $\mathrm{CO}_{2}$ capture can be used [3]. Technologies that separate this gas from gas streams have been used for many decades. The main objective of the industries is $\mathrm{CO}_{2}$ removal to meet the required downstream product specifications, whether natural gas, hydrogen, or chemicals.

In pre-combustion $\mathrm{CO}_{2}$ capture systems, the fuel source is decarbonized before combustion. More recently, in anticipation of the requirements to limit $\mathrm{CO}_{2}$ emissions, plants design have been improved to convert the gas produced from gasification to hydrogen and $\mathrm{CO}_{2}$ and remove $\mathrm{CO}_{2}$ before the combustion of the hydrogen-rich gas in the turbine [31]. The gasification or partial oxidation process combines the reacting coal with steam and oxygen at high pressure and temperature. The product is a gaseous fuel consisting mainly of carbon monoxide and hydrogen, called synthesis gas or syngas.

After this, syngas is converted to more hydrogen and carbon dioxide by adding steam at a lower temperature. This is the Water Gas Shift Reaction (WGS) (Equation (1)). Before the combustion of the hydrogen-rich gas in the gas turbine, the $\mathrm{CO}_{2}$ is captured. The concentration can be in the range of $15-60 \%$ (dry basis / $\%$ volume), and the total pressure is typically $2-7 \mathrm{MPa}[3,31,32]$ :

$$
\begin{gathered}
\mathrm{CO}+\mathrm{O} \leftrightarrow \mathrm{CO}_{2}+\mathrm{H}_{2} \\
\Delta \mathrm{H}=-40.6 \mathrm{~kJ} \mathrm{~mol}^{-1}
\end{gathered}
$$


The WGS reaction is the desired route for industrial applications, most commonly in conjunction with the Fischer-Tropsch (FT) reaction to synthesize hydrocarbon fuels from syngas. The conditions used for the FT reaction lie in the range of $200-375{ }^{\circ} \mathrm{C}$; lower temperatures for long-chain alkanes and higher temperatures for shorter [32].

When compared with post-combustion process, $\mathrm{CO}_{2}$ presents a higher concentration in the pre-combustion gas stream $\left(>20 \%\right.$ in the $\mathrm{H}_{2}+\mathrm{CO}_{2}$ stream vs. $5-15 \%$ in a postcombustion flue gas stream). Then, $\mathrm{CO}_{2} / \mathrm{H}_{2}$ separation is somewhat more straightforward than the $\mathrm{CO}_{2} / \mathrm{N}_{2}$ separation in the post-combustion process due to the difference in molecular weights and molecular kinetic diameters [33].

$\mathrm{CO}_{2}$ and $\mathrm{H}_{2}$ can be separated using several technologies. Solvent-based $\mathrm{CO}_{2}$ capture can be applied by chemical or physical (such as the Selexol and Fluor processes) absorption of $\mathrm{CO}_{2}$ from syngas into a liquid carrier and regenerating the absorption liquid by increasing the temperature or reducing the pressure to break the absorbent- $\mathrm{CO}_{2}$ bond [34]. Sorbent, membrane, and hybrid systems that combine attributes from multiple technologies are under investigation to reduce costs and energy penalties, as well as, to improve performance [35].

\subsection{Oxy-Combustion}

The oxy-combustion processes were designed to remove the bulk nitrogen from the air before combustion. A combination of oxygen (95\% of purity, approximately) and recycled flue gas is used for the fuel combustion. A mixture with $\mathrm{CO}_{2}$ and $\mathrm{H}_{2} \mathrm{O}$ is generated by recycling the flue gas, and this mixture is ready for sequestration without stripping of the $\mathrm{CO}_{2}$ from the gas stream [36]. The flame temperature is controlled by the amount of recycled flue gas. No chemical solvent or physical sorbent is required to separate $\mathrm{CO}_{2}$ from the flue gas due to the high concentration in the stream. The carbon dioxide rich flue gas would then be delivered by pipeline to be sequestered.

This system was developed as an alternative to the more conventional post-combustion process in coal-fired power plants. The main reason is the reduced cost of oxy-combustion when compared with post-combustion. However, although good results were obtained in laboratory scale and pilot plants, commercial plants use is still scarce [3].

\subsection{Post-Combustion}

Post-combustion $\mathrm{CO}_{2}$ capture systems have been used for many decades, and in this process, the $\mathrm{CO}_{2}$ is captured from the products of burning fossil fuels (coal, natural gas, or oil) or combustion exhaust gases. The flue gas passes through a liquid solvent, solid adsorbent, membrane, or another medium, depending on the method/technology, allowing the separation of the $\mathrm{CO}_{2}$ from the mixture. After that, $\mathrm{CO}_{2}$ can be transported and stored.

The drawback of post-combustion carbon capture is the low carbon dioxide concentration in the flue gases, which leads to a relatively high energy penalty and high costs of carbon capture. On the other hand, pre-combustion strives to reduce these penalties by decarbonizing the process stream before combustion, resulting in more favorable conditions and more flexible implementation, significantly reducing capture costs [37].

Several technologies can be applied for separating or capturing $\mathrm{CO}_{2}$ from a mixture of gases in an industrial process. The purification step and the technical approach used depend on the gas stream conditions, such as temperature, pressure, and concentration, and on the product purity required.

The captured and purified gas will be transported to its final destination. In the case of CCS, a pipeline is necessary to transport captured $\mathrm{CO}_{2}$ for a storage site. When CCU is applied, a spur on the pipeline can take a slipstream from the main flow to be diverted to the chemicals or synthetic fuels plant. At the end of the supply chain, a minor quantity of $\mathrm{CO}_{2}$ could still be emitted or stored [38]. 


\subsection{Technologies for $\mathrm{CO}_{2}$ Capture}

Figure 7 shows technical approaches available for $\mathrm{CO}_{2}$ separation and capture.

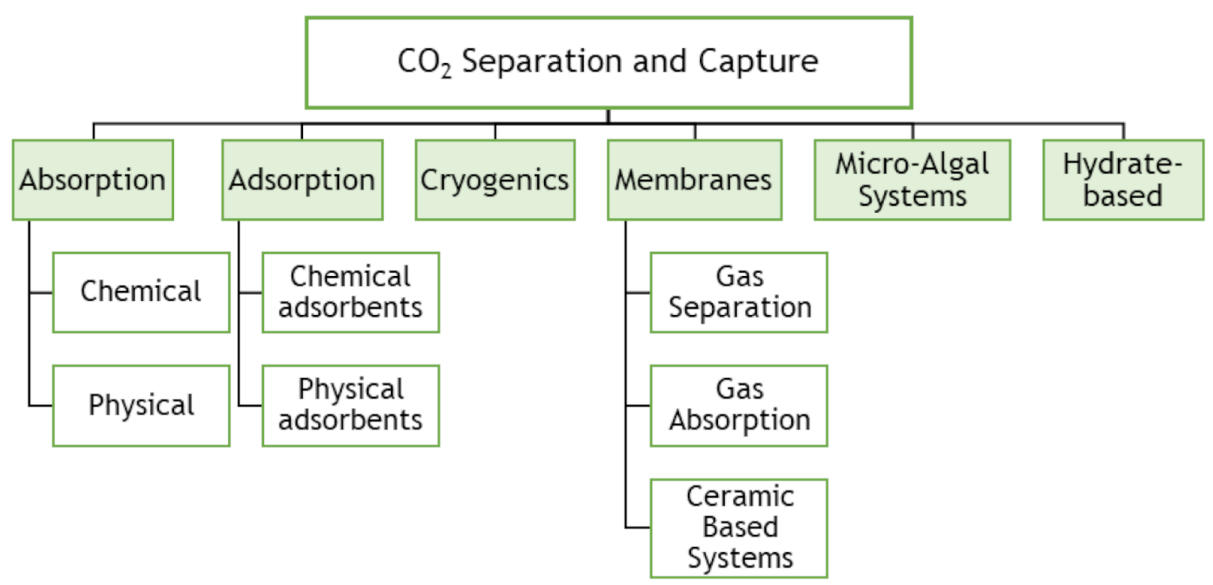

Figure 7. Technical options for $\mathrm{CO}_{2}$ capture processes (adapted from Songolzadeh, Ravanchi and Soleimani [21]).

The most common process used to separate the $\mathrm{CO}_{2}$ from natural gas, refinery offgases, and synthesis gas processing is absorption technology [39]. This is characterized by using a liquid/solvent that selectively absorbs $\mathrm{CO}_{2}$ from a gas stream. Afterwards, the solvent can be regenerated through a stripping or regenerative process by heating and/or pressurization [40]. Absorption processes can be chemical absorption, used in pre-combustion or post-combustion capture, or physical absorption, primarily used in pre-combustion capture. Selexol (with dimethyl ethers of polyethylene glycol solvent), Rectisol (with methanol solvent), and Purisol (with N-methyl-2-pyrolidone as solvent) are the most common physical processes. Typical chemical solvents are primary amines such as monoethanolamine (MEA) and 2-amino-2-methyl-1-propanol (AMP), secondary amines such as diethanolamine (DEA), and ternary amines such as methyldiethanolamine (MDEA) $[39,41]$. However, in this type of process, gas streams are required at high pressure. Plants for $\mathrm{CO}_{2}$ capture with processes based on chemical absorption using MEA solvent were developed over 75 years ago to remove acidic gas impurities like $\mathrm{H}_{2} \mathrm{~S}$ and $\mathrm{CO}_{2}$ from natural gas streams. Afterwards, the process was adapted to treat flue gas streams, and with this technology, about 85 to $95 \%$ of the $\mathrm{CO}_{2}$ is captured, and a product stream of $\mathrm{CO}_{2}$ can be produced with a purity higher than $99 \%$ [42].

The major challenges for $\mathrm{CO}_{2}$ capture from flue gases by absorption processes are the sizeable volumetric flow rates at atmospheric pressure with large amounts of $\mathrm{CO}_{2}$ at low partial pressures $\left(10-15 \%\right.$ of $\left.\mathrm{CO}_{2}\right)$ at $40{ }^{\circ} \mathrm{C}$. Then, the process presents several disadvantages, which are the high energy consumption due to the high thermal energy required, around $4.0 \mathrm{GJ} / \mathrm{t}$ of $\mathrm{CO}_{2}$ captured [41] (considering $30 \mathrm{wt} \% \mathrm{MEA}$ and $90 \% \mathrm{CO}_{2}$ removal), the presence of SOx and NOx contaminants, and the high oxygen partial pressure, which hinders the implementation of amine absorption process [43]. Besides, it leads to corrosive product formation due to the solvents' thermal and oxidative solvent degradation. There are many studies about processual alternatives to reduce the costs involved in power plants to reduce the operating costs. Besides the physical and chemical absorption methods discussed above, other methods could be implemented, as verified in Figure 7 .

Gas separation through adsorption processes can be used in pre- and post-combustion capture and are promising alternative separation techniques characterized by solid adsorbents capable of reversibly capturing $\mathrm{CO}_{2}$. Novel adsorbent materials for $\mathrm{CO}_{2}$ capture with specific properties can adsorb large amounts of $\mathrm{CO}_{2}$ to be used or stored, being these materials instruments for $\mathrm{CO}_{2}$ utilization and storage. Adsorbents are porous solids and have a large surface area per unit mass. Each type of molecule or component creates different interactions with the adsorbent surface, leading to an eventual separation [44]. 
There are many types of adsorbents, which could be applied to $\mathrm{CO}_{2}$ capture by physical adsorption processes, including activated carbons, carbon fibers, zeolites [45], metal-organic frameworks [46], and organic-inorganic hybrid materials [47,48]. The adsorbent should be chosen taking into account economic and operational criteria, which are (i) high adsorption capacity for the target gas component, i.e., $\mathrm{CO}_{2}$, leading to the reduction of the adsorbent quantity and process equipment size; (ii) high $\mathrm{CO}_{2}$ selectivity, representing a high adsorption capacity ratio between $\mathrm{CO}_{2}$ and the other components in the stream, such as, nitrogen; (iii) fast adsorption and desorption kinetics; (iv) good physical and chemical stability during the cycles and regeneration steps; (v) be regenerable by modest pressure decrease or temperature increase, leading to the minimization of the operating energy costs. Furthermore, the adsorbent should ideally also have robust performance in the presence of moisture and other contaminants that may be present in the gas stream to treat. Then, there are essential features that should be considered for a successful operation of adsorbent material, such as composition, particle size, pore size, and pore connectivity.

Depending on the regeneration method, adsorption processes can be denominated as pressure swing adsorption (PSA), temperature swing adsorption (TSA), and electrical swing adsorption (ESA) $[49,50]$.

Cryogenic carbon capture utilizes the principle of separation based on the cooling of $\mathrm{CO}_{2}$ to low temperature. The $\mathrm{CO}_{2}$ is separated from the flue gas mixture after cooling this gas below $-73.3^{\circ} \mathrm{C}$ at atmospheric pressure. After this, $\mathrm{CO}_{2}$ is pressurized and delivered at pipeline pressure. Cryogenic separation can be applied for post-combustion processes in two different ways. In one of these methods, $\mathrm{CO}_{2}$ can be de-sublimated to solid $\mathrm{CO}_{2}$ on the heat exchangers, further heated and pressurized to obtain liquid $\mathrm{CO}_{2}$ in the recovery stage. Clodic and Younes [51] proposed this type of separation. Tuinier et al. [52] proposed another method, with the use of packed beds for de-sublimation of $\mathrm{CO}_{2} \cdot \mathrm{CO}_{2}$ is recovered from the packing material by feeding a fresh gas stream to increase the temperature and enhance the concentration of the $\mathrm{CO}_{2}$ recovered from the packed bed [53]. It may be a good technique because it does not involve any additional chemicals in the separation process. However, the high compression power requirements for this method are the major disadvantage [54].

Membranes are another potential alternative to conventional solvent absorption technology. The difference in physical and/or chemical interactions between gases and membrane materials is responsible for the $\mathrm{CO}_{2}$ separation. The method presents many advantages, such as reduced equipment size, lower energy requirements, simplicity in the process, among others. Nevertheless, in the post-combustion process, particularly in the $\mathrm{CO}_{2} / \mathrm{N}_{2}$ separation, due to the relatively low $\mathrm{CO}_{2}$ concentration and pressure, the driving force for membranes to perform appropriately is weak, making their implementation difficult [55].

Another potential technique for removing $\mathrm{CO}_{2}$ from flue gases is microalgae. Microalgae are microscopic organisms that typically grow suspended in water and are driven by the same photosynthetic process as higher plants [56].

Microalgal cells are sunlight-driven cell factories that can convert carbon dioxide into raw materials for producing biofuels (e.g., biohydrogen, biodiesel, and bioethanol), animal food chemical feedstocks, and high-value bioactive compounds [56].

The ability of these cells to absorb $\mathrm{CO}_{2}$ can be applied as an attractive alternative for $\mathrm{CO}_{2}$ sequestration. $\mathrm{CO}_{2}$ fixation and storage via microalgae are essentially photosynthesis, transforming water and $\mathrm{CO}_{2}$ into organic compounds without extra energy addition or consumption and secondary pollution.

Hydrate-based $\mathrm{CO}_{2}$ capture (HBCC) technology emerges as a potential solution for $\mathrm{CO}_{2}$ capture from gas streaming, e.g., fromCO $\mathrm{C}_{2} / \mathrm{N}_{2}$ or from $\mathrm{CO}_{2} / \mathrm{H}_{2}$ of fossil fuel power plants. This technology is based on the hydrate cages formation by water molecules at high pressure and low temperature, where $\mathrm{CO}_{2}$ molecules stay enclathrated, allowing their separation. It is estimated that this technology could have a cost reduction of $\mathrm{CO}_{2}$ capture of about $45 \%$ when compared with the chemical absorption technology [57]. Recently, studies involving hydrate-base $\mathrm{CO}_{2}$ capture and storage have increased [58,59]. 


\subsection{Current Progress of CCUS Facilities}

Since 1972, CCS has been applied to capture $\mathrm{CO}_{2}$ from an extensive range of sectors and industries [7]. Typically, the progress of technology development contains a series of scale-up steps: first, laboratory scale or bench; second, pilot-scale; third, demonstrationscale; fourth, commercial scale. Currently, there are eighteen large-scale facilities in operation in the world, five under construction, and twenty in various stages of development [14] (see Table 1).

Table 1. Current development progress of technologies in terms of technology readiness level (TRL): carbon capture; transport; storage; and utilization (adapted from Bui [13],Consoli [14]).

\begin{tabular}{|c|c|}
\hline Technology Readiness Level & Current Development \\
\hline TRL1 & Concept \\
\hline TRL2 & Formulation \\
\hline S & Ocean Storage \\
\hline TRL3 & Proof of concept (lab tests) \\
\hline (c) & Ionic Liquids-Post-combustion \\
\hline (c) & BECCS Power \\
\hline (C) & Low T separation-Pre-combustion \\
\hline (c) & Membranes dense inorganic $\left(\mathrm{CO}_{2}\right.$ separation $)$ \\
\hline s & Mineral storage \\
\hline TRL4 & Lab prototype \\
\hline (C) & Oxy-combustion gas turbine (water cycle) \\
\hline TRL5 & Lab-scale plant \\
\hline (C) & $\begin{array}{c}\begin{array}{c}\text { Membranes dense inorganic ( } \mathrm{H}_{2} \text { separation for } \\
\text { reformer) }\end{array}\end{array}$ \\
\hline TRL6 & Pilot plant \\
\hline (C) & Membranes polymeric (power plants) \\
\hline (c) & Biphasic solvents-Post-combustion \\
\hline (c) & Chemical looping combustion (CLC) \\
\hline (c) & Calcium carbonate looping $(\mathrm{CaL})$ \\
\hline u & $\mathrm{CO}_{2}$ utilization (non-EOR) \\
\hline TRL7 & Demonstration \\
\hline (c) & Membranes polymeric (NG industry) \\
\hline (c) & Pre-combustion IGCC + CCS \\
\hline (C) & Oxy-combustion coal power plant \\
\hline (C) & Adsorption-Post-combustion \\
\hline (c) & BECCS industry \\
\hline (c) & DAC \\
\hline s & Depleted oil \& gas fields \\
\hline s & $\mathrm{CO}_{2}$-EGR \\
\hline
\end{tabular}


Table 1. Cont.

\begin{tabular}{cc}
\hline Technology Readiness Level & Current Development \\
\hline TRL8 & Commercial Refinement required \\
\hline TRL9 & Commercial \\
\hline C & Post-combustion amines (power plants) \\
C & Pre-combustion NG processing \\
C & Transport on-shore \& off-shore pipelines \\
T & Transport ships \\
S & Saline formations \\
S & CCUS
\end{tabular}

Notes: BECCS corresponds to bioenergy with CCS, IGCC corresponds to integrated gasification combined cycle, EGR corresponds to enhanced gas recovery, EOR corresponds to enhanced oil recovery, NG corresponds to natural gas; $\mathrm{CO}_{2}$ utilization (non-EOR) reflects a wide range of technologies, most of which have been demonstrated conceptually at the lab scale. C-Capture; T-Transport; U-Utilization; S-Storage.

\subsection{Global Facilities of CCUS}

More than 30 new integrated CCUS facilities have been announced since 2007, mostly in the United States and Europe, although projects are also planned in China, Australia, Korea, the Middle East and New Zealand [60]. One of them was developed by Svante [61]. Started in 2007, Svante designed and built a $\mathrm{CO}_{2}$ capture facility to capture half a tonne of carbon per day. This technology captures carbon dioxide from flue gas, concentrates it, then releases it for safe storage or industrial use, in $60 \mathrm{~s}$. Today, Svante has several industrial-scale carbon capture projects and collaborations.

Another application example is Air Products. This company possesses solutions for $\mathrm{CO}_{2}$ capture from fossil fuel conversion before it reaches the atmosphere. The technology has designed and constructed a large-scale system to capture $\mathrm{CO}_{2}$ from steam methane reformers, which are located within the Valero Refinery in Port Arthur (TX, USA). Air Products has a technology that already separate, purify and transport $\mathrm{CO}_{2}$ from natural gas reforming, management of syngas from gasification, and oxyfuel combustion in markets such as steel and glass [62].

The Global CCS Institute provides a database of CCUS facilities operating in the world. This organization establishes as large-scale integrated CCSU facilities in its database comprising the capture, transport, and storage of $\mathrm{CO}_{2}$ at a scale of at least $800 \mathrm{kt}$ of $\mathrm{CO}_{2}$ annually for a coal-based power plant, or at least $400 \mathrm{kt}$ of $\mathrm{CO}_{2}$ annually for other emission-intensive industrial facilities (natural gas-based power generation is included). The remaining facilities and initiatives in the database are mentioned as in advancement/deployment status [63]. The last update of the database refers to October 2019.

Currently, there are several CCS facilities in Europe, and they can be classified in three different classes:

(1) Commercial Carbon Capture and Storage Facilities- $\mathrm{CO}_{2}$ can be captured and transported to be permanently stored; have economic lives similar to the host facility whose $\mathrm{CO}_{2}$ is captured; must support a commercial return while operating and meet regulatory requirements;

(2) Carbon Capture and Storage Hubs-Commercial facilities although not having a full-chain (capture, transport and storage) operation; several models are considered, combining multiple capture facilities, or $\mathrm{CO}_{2}$ transport and storage;

(3) Pilot and Demonstration Facilities- $\mathrm{CO}_{2}$ is captured for testing, developing or demonstrating CCS technologies/processes; $\mathrm{CO}_{2}$ captured may or may not be transported for permanent storage; A commercial return during operation is not expected.

Taking into account this classification, actually in Europe (accessed data at 1st of April 2021), there are 13 commercial CCS Facilities, two CCS Hubs (one in The Netherlands and 
another one in United Kingdom), and 29 Pilot and Demonstration facilities [63]. Figure 8 shows the map of the worldwide distribution of CCUS facilities, focusing on Europe.

\section{Facility Category Large-scale Pilot/ Demonstration Test Centre Utilisation Other Initiatives}

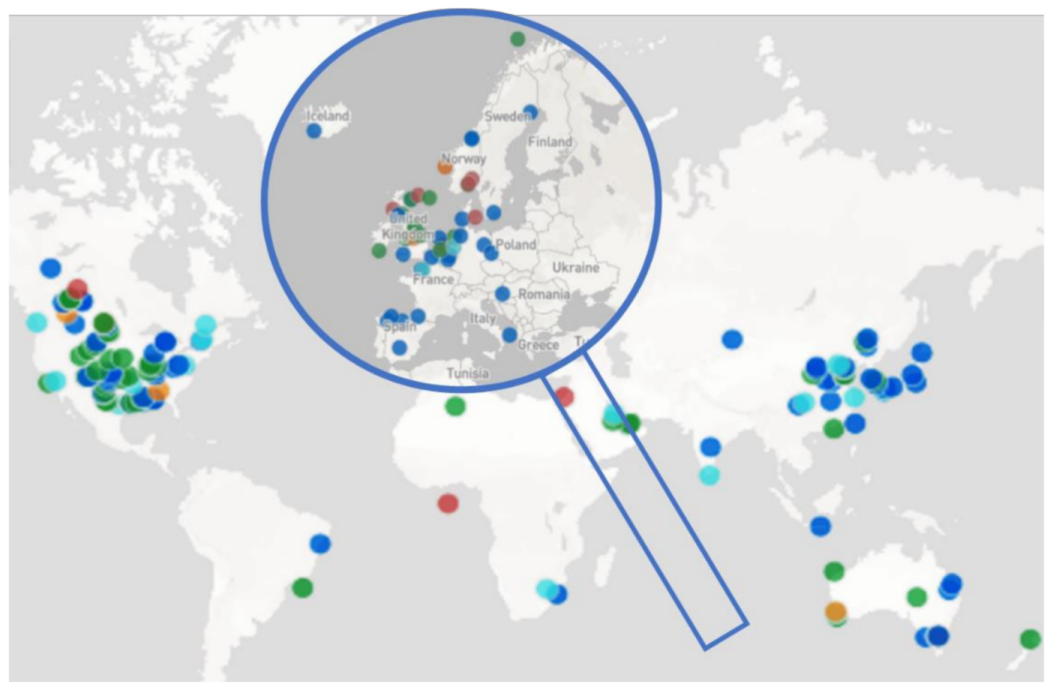

Figure 8. Worldwide distribution of CCUS facilities divided by categories, expanded in Europe (adapted from Institute [63]).

Table 2 summarises the commercial CCS facilities that are working in Europe. Other facilities are under study in test centers or the pilot or demonstration phase. Table A1 to Table A4 (in the Appendix A) summarise these facilities.

Table 2. Summary of large-scale commercial CCS facilities that are working in Europe (Notes: Status: ED—Early Development; AD—Advanced Development; O-Operational; C-Completed; In C-In Construction; Data: represents the starting year of the project; Mtpa-Million tonnes per annum; tpa—tonnens per annum; tpd—tonnes per day).

\begin{tabular}{|c|c|c|c|c|c|}
\hline Name & Status & Country & Data & Industry & Observations \\
\hline $\begin{array}{c}\text { Acorn Scalable } \\
\text { CCS Development }\end{array}$ & ED & UK & $2020 s$ & Oil Refining & $\begin{array}{l}\text { Scale-up of the pilot project Acorn } \\
\text { (Minimum Viable CCS Development) }\end{array}$ \\
\hline $\begin{array}{l}\text { Caledonia Clean } \\
\text { Energy }\end{array}$ & ED & UK & 2024 & Power generation & $\begin{array}{l}\mathrm{CO}_{2} \text { capture would be } 3 \mathrm{Mtpa} \text { and } \\
\text { transported via re-purposed pipeline for } \\
\text { geological storage in the } \\
\text { North Sea of Scotland }\end{array}$ \\
\hline $\begin{array}{l}\text { Drax BECCS } \\
\text { Project }\end{array}$ & ED & UK & 2027 & Power generation & $\begin{array}{l}\text { Aims to capture } 4 \text { Mtpa from one ( } 660 \mathrm{MW}) \\
\text { of the biomass-fired power lines at the } \\
\text { UK's biggest power station by } 2027\end{array}$ \\
\hline Ervia Cork CCS & ED & Ireland & 2028 & $\begin{array}{l}\text { Power generation } \\
\text { and refining }\end{array}$ & $\begin{array}{l}\mathrm{CO}_{2} \text { captured initially from the } \\
\text { two-modern gas-fired, combined-cycle gas } \\
\text { turbine power stations and Ireland's only } \\
\text { oil refining business; transported via a } \\
\text { pipeline network to sites in the } \\
\text { Kinsale Gas Field }\end{array}$ \\
\hline $\begin{array}{l}\text { Hydrogen to } \\
\text { Humber Saltend } \\
(\mathrm{H} 2 \mathrm{H})\end{array}$ & ED & UK & $2026-2027$ & $\begin{array}{l}\text { Hydrogen } \\
\text { production }\end{array}$ & $\begin{array}{l}\mathrm{H} 2 \mathrm{H} \text { Saltend is in development to produce } \\
\text { blue hydrogen via a new build } 600 \mathrm{MW} \\
\text { autothermal reformer to decarbonize Triton } \\
\text { Power's gas-fired power plant; up to } \\
1.4 \text { million tonnes of } \mathrm{CO}_{2} \text { will be captured. }\end{array}$ \\
\hline $\begin{array}{c}\text { Hydrogen } 2 \\
\text { Magnum (H2M) }\end{array}$ & ED & Netherlands & 2004 & Power generation & $\begin{array}{l}\text { H2M produce hydrogen to be used in gas } \\
\text { power plant in Eemshaven, Germany, } \\
\text { Equinor, Vattenfall and Gassunie }\end{array}$ \\
\hline
\end{tabular}


Table 2. Cont

\begin{tabular}{|c|c|c|c|c|c|}
\hline Name & Status & Country & Data & Industry & Observations \\
\hline HyNet North West & ED & UK & Mid 2020s & $\begin{array}{l}\text { Hydrogen } \\
\text { Production }\end{array}$ & $\begin{array}{l}\mathrm{CO}_{2} \text { is planned to be captured from the } \\
\text { Hydrogen Production \& Carbon Capture } \\
\text { plant, and transported, together with } \\
\text { captured } \mathrm{CO}_{2} \text { from existing } \\
\text { nearby industrial sites }\end{array}$ \\
\hline $\begin{array}{l}\text { Langskip } \\
\text { CCS-Fortum Oslo } \\
\text { Varme }\end{array}$ & $\mathrm{AD}$ & Norway & 2024 & Waste Incineratiom & $\begin{array}{l}\text { It is in construction to capture about } \\
0.4 \mathrm{Mtpa} \text { of } \mathrm{CO}_{2} \text { by } 2024 \text { from its cement } \\
\text { production plat in southern Norway; the } \\
\text { offshore Aurora area has been evaluated as } \\
\text { original storage site and will involve a } \\
\text { combined ship and pipeline } \\
\text { transportation system. }\end{array}$ \\
\hline Net Zero Teesside & ED & UK & $2020 s$ & Various & $\begin{array}{c}\text { Cluster of leading energy-intensive } \\
\text { companies to examine the opportunity to } \\
\text { build one of Europe's first CCS equipped } \\
\text { industrial zones in Tees Valley, UK; starts } \\
\text { with a capture capacity of } 0.8 \mathrm{Mtpa} \text {, that } \\
\text { could grow up to } 10 \mathrm{Mtpa} \mathrm{CO}_{2} \\
\text { transported via pipeline to an offshore site } \\
\text { in the North Sea }\end{array}$ \\
\hline $\begin{array}{l}\text { Northern Gas } \\
\text { Network H21 } \\
\text { North of England }\end{array}$ & $\mathrm{AD}$ & UK & 2026 & $\begin{array}{l}\text { Hydrogen } \\
\text { production }\end{array}$ & $\begin{array}{c}\text { H21 aims to convert the UK gas grid from } \\
\text { natural gas (methane) to } \\
\text { zero-carbon hydrogen }\end{array}$ \\
\hline $\begin{array}{c}\text { Norway Full Chain } \\
\text { CCS }\end{array}$ & $\mathrm{AD}$ & Norway & 2023-2024 & Various & $\begin{array}{c}\text { Aim of } 0.8 \mathrm{Mtpa} \text {; Capture } \mathrm{CO}_{2} \text { studies are } \\
\text { being undertaken by two proponents } \\
\text { involved in cement production and a } \\
\text { waste-to-energy recovery plant, both in } \\
\text { southern Norway; } \mathrm{CO}_{2} \text { would be } \\
\text { transported via ship and pipeline to an } \\
\text { offshore in the Smeaheia area }\end{array}$ \\
\hline $\begin{array}{l}\text { Port of Rotterdam } \\
\text { CCUS Backbone } \\
\text { Initiative (Porthos) }\end{array}$ & $\mathrm{AD}$ & Netherlands & 2023 & Various & $\begin{array}{l}\text { The ambition is to store } 2 \text { Mtpa from } 2023 \\
\text { on, a total that will run up to } \\
5 \text { Mtpa by } 2030\end{array}$ \\
\hline $\begin{array}{c}\text { Sleipner } \mathrm{CO}_{2} \\
\text { Storage }\end{array}$ & $\mathrm{O}$ & Norway & 1996 & $\begin{array}{l}\text { Natural Gas } \\
\text { Processing }\end{array}$ & $\begin{array}{l}\text { The Spleipner } \mathrm{CO}_{2} \text { storage facility was the } \\
\text { first (since 1996) in the world to inject } \mathrm{CO}_{2} \\
\text { into a dedicated geological storage (located } \\
\text { offshore in Norway); Approximately } \\
0.85 \text { Mtpa is injected and over } 17 \text { Mtpa has } \\
\text { been injected since inception to } 2019\end{array}$ \\
\hline $\begin{array}{c}\text { Snohvit } \mathrm{CO}_{2} \\
\text { Storage }\end{array}$ & $\mathrm{O}$ & Norway & 2008 & $\begin{array}{l}\text { Natural Gas } \\
\text { Processing }\end{array}$ & $\begin{array}{c}\mathrm{CO}_{2} \text { is captured at an } \mathrm{LNG} \text { facility on the } \\
\text { island of Melkoya, Norway; designed to } \\
\text { capture } 0.7 \mathrm{Mtpa} \text {, and } \mathrm{CO}_{2} \text { is transported } \\
\text { via pipeline back to the Snohvit field } \\
\text { offshore, where more than } 4 \text { Mtpa has been } \\
\text { stored to date since } 2008\end{array}$ \\
\hline $\begin{array}{c}\text { The Clean Gas } \\
\text { Project }\end{array}$ & ED & UK & 2025 & Power generation & $\begin{array}{l}\text { Natural gas will be used to generate power } \\
\text { via a Combined Cycle Gas turbine gas-fired } \\
\text { generation station, with } \mathrm{CO}_{2} \text { captured and } \\
\text { transported by pipeline for storage in a } \\
\text { formation under the Southern North Sea }\end{array}$ \\
\hline
\end{tabular}

As demonstrated with the set of works in development presented in Table 2, great efforts have been made to apply capture, storage, and utilization processes in plants. However, there are only a few large-scale CCS plants in operation in Europe so far. This is related to a series of obstacles preventing this technology from being adopted more widely. In most European countries, the nature of the challenges can be political, economic, technical, and social [64-67].

- Political: lack of political commitment with CCS by some member states; 
- Economic: high investment, high operational costs, lack of competitiveness compared with other low carbon technologies; no financial compensation for the additional capital and operating costs associated with CCS; Long-term funding commitments from various public and private sources ensure the continuity of research programs which are necessary for the development of $\mathrm{CO}_{2}$ utilization;

- Technical: lack of infrastructures for transport and storage;

- Social: CCS is unknown for the overall public; resistance to $\mathrm{CO}_{2}$ storage concept; environmental risks concerning health and water pollution.

Efforts have been made to combat these barriers. As mentioned, to reach the targets defined in the Paris Agreement, immediate/prompt action would be required to reduce $\mathrm{CO}_{2}$ emissions. Processes related to CCS can be classified as carbon-positive, near carbonneutral, or carbon-negative. Carbon positive corresponds to the majority of the processes, which still emit $\mathrm{CO}_{2}$ for the atmosphere. Carbon-neutral and carbon-negative emissions are responsible for zero carbon emissions (neutral) and $\mathrm{CO}_{2}$ emissions reduction to the atmosphere. Examples of the "negative" processes able to capture $\mathrm{CO}_{2}$ are Bioenergy with Carbon Capture and Storage (BECCS) and Direct Air Capture (DAC).

\section{Climate Positive Solutions}

\subsection{Bioenergy with Carbon Capture and Storage (BECCS)}

Bioenergy has always been present in the world and used by humans to produce heat. Bioenergy is used in vehicles as fuel (bioethanol) and provides electricity by burning biomass [14]. BECCS is part of the broader CCS technology and is emerging as one of the most advanced technologies to decarbonize emission-intensive industries and sectors and enable negative emissions [14]. This is a group of different technologies to produce energy from biomass and $\mathrm{CO}_{2}$ storage.

This process using biomass as a fuel source because biomass feedstock draws down $\mathrm{CO}_{2}$ from the atmosphere through photosynthesis. Biomass is burned (combusted or converted) to biofuel, using digestion or fermentation processes. The heat generated can be used for electricity generation or industrial applications, such as cement, pulp and papermaking, waste incineration, steel and iron, and petrochemical. Conversion leads to gaseous (when digestion is applied) or liquid (when fermentation occurs) fuels production. In the liquid case, it leads to the production of bioethanol. Then, $\mathrm{CO}_{2}$ is captured from a biomass energy conversion and permanently stored in a suitable geological formation. At the end of the process, the $\mathrm{CO}_{2}$ emitted during bioenergy production, the $\mathrm{CO}_{2}$ transported, converted, and utilized should be lower than the $\mathrm{CO}_{2}$ stored to achieve the primary target-negative emissions. Figure 9 presents a scheme of the BECCS.

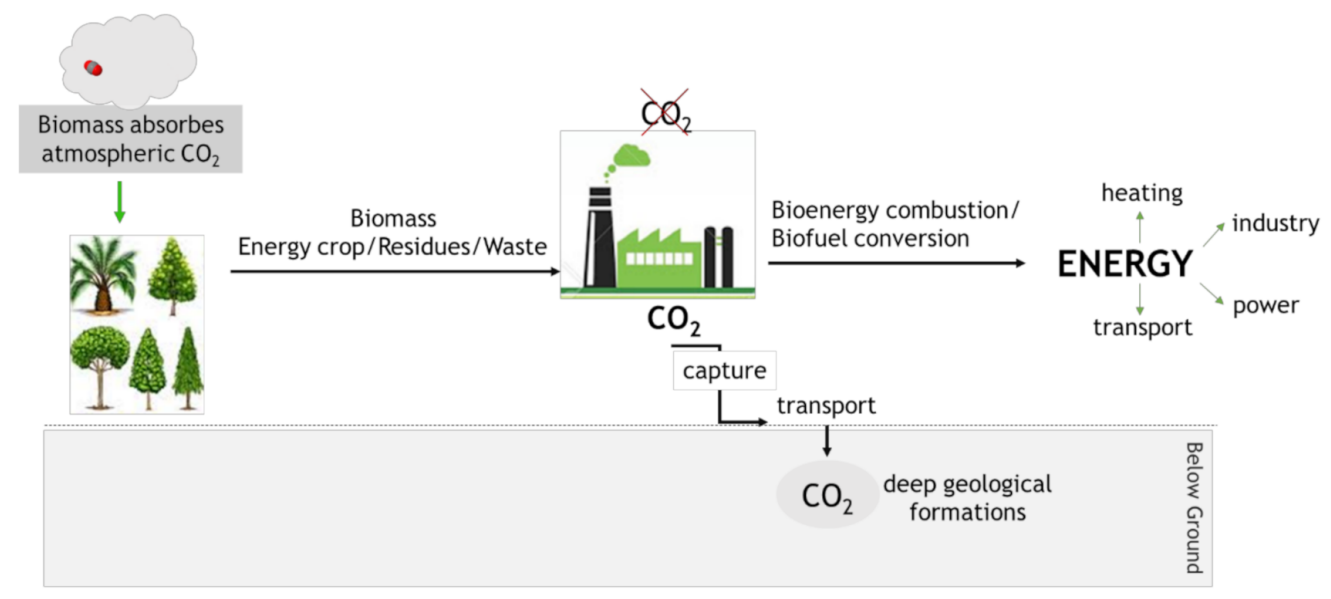

Figure 9. Scheme of bioenergy and carbon capture and storage (BECCS) (adapted from Consoli [14]). 
The Global CCS Institute (2019 data) [14] reports the existence of five facilities (one large-scale and four small-scale) actively operating using BECCS technologies worldwide. Approximately 1.5 million tonnes of $\mathrm{CO}_{2}$ per annum (Mtpa) are captured by these facilities. Table 3 shows a description of these BECCS facilities and the planned projects.

Table 3. Brief description of BECCS facilities operating today and planned projects (Notes: Mtpamillion tonnes per annum; tpa-tonnes per annum; tpd-tonnes per day).

\begin{tabular}{|c|}
\hline Operating Today-Five Facilities in USA \\
\hline Illinois CCS (USA)-1 Mtpa \\
\hline $\begin{array}{c}\text { Ethanol is produced from corn at its Decatur plant, producing } \mathrm{CO}_{2} \text { as part of the } \\
\text { fermentation process }\end{array}$ \\
\hline Kansas Arkalon (USA)—200,000 tpa \\
\hline $\begin{array}{c}\mathrm{CO}_{2} \text { is compressed and piped from an ethanol plant in Kansas to Booker and Farnsworth Oil } \\
\text { Units in Texas for EOR }\end{array}$ \\
\hline Bonanza CCS (USA)-100,000 tpa \\
\hline $\mathrm{CO}_{2}$ is compressed and piped from an ethanol plant in Kansas to nearby Stewart Oil field for EOR \\
\hline Husky Energy $\mathrm{CO}_{2}$ Injection (Canada)-250 tpd \\
\hline $\begin{array}{c}\mathrm{CO}_{2} \text { is compressed and trucked from an ethanol plant (Saskatchewan) to nearby Lashburn and } \\
\text { Tangleflags oil fields for EOR }\end{array}$ \\
\hline Farnsworth (USA) - 600,000 tonnes \\
\hline $\begin{array}{l}\mathrm{CO}_{2} \text { is compressed from an ethanol plant (Kansas) and fertiliser plant (Texas) and piped to } \\
\text { Farnsworth oil field for EOR }\end{array}$ \\
\hline Planning-One facility in Asia and Two facilities in Europe \\
\hline Mikawa Power Plant (Japan) \\
\hline $\begin{array}{l}\text { Retrofit of a 49-MW unit power plant (Omuta, Fukuoka Prefecture) to accept } 100 \% \text { of tonne of } \\
\text { biomass with a } \mathrm{CO}_{2} \text { capture facility.Current situation: identify a secure offshore storage site }\end{array}$ \\
\hline Drax Power Plant (UK) \\
\hline $\begin{array}{l}\text { Biomass power generation pilot (North Yorkshire): high potential to develop } \mathrm{CO}_{2} \\
\text { capture and storage }\end{array}$ \\
\hline Drax Power Plant (UK) \\
\hline $\begin{array}{l}\text { BECCS integration into waste-to-energy and a cement plants: } \\
\text { Plant: plans to capture } 400,000 \text { tpa of } \mathrm{CO}_{2} \text { (Klemetsrud waste-to-energy)Currently co-fires up to } \\
30 \% \text { biomass and plans to capture up to } 400,000 \text { tpa of } \mathrm{CO}_{2} \text { (Norcem Cement plant) } \\
\mathrm{CO}_{2} \text { will be sent to a storage site (Norwegian North Sea) from waste-to-energy and cement plants }\end{array}$ \\
\hline
\end{tabular}

\subsection{Direct Air Capture (DAC)}

Industrial applications containing air capture technology are not new and have existed since 1930 [68].

In contrast to carbon dioxide capture from sources, such as cement or biomass plants, direct air capture (DAC) is a technology that captures $\mathrm{CO}_{2}$ directly from the ambient air and generates an enriched stream of $\mathrm{CO}_{2}$ for storage or use. The process can be denominated as physical or chemical separation. Figure 10 presents a scheme of the DAC process.

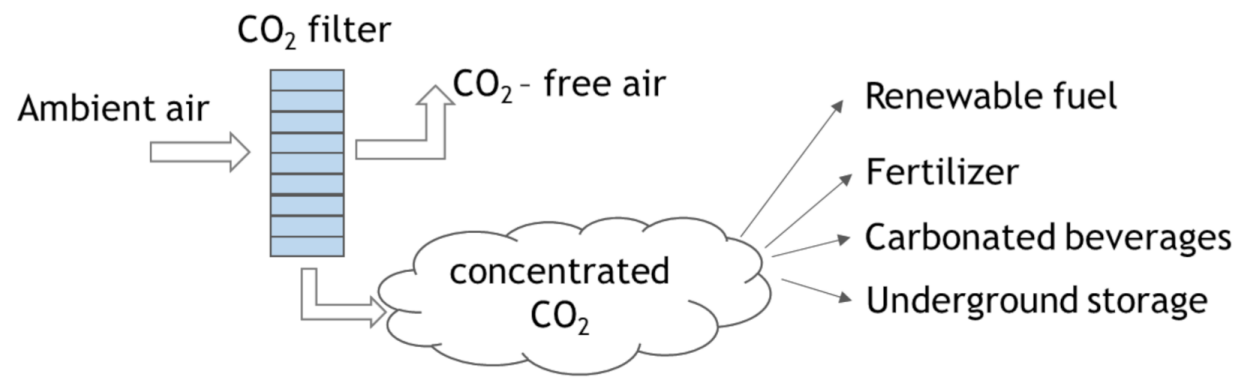

Figure 10. Scheme of DAC (adapted from Gutknecht [69]). 
It is common to divide the DAC process into three different classes, regarding the approach to separate $\mathrm{CO}_{2}$ from the air: chemical, cryogenic, and membranes [70].

Two technology approaches are being used to extract $\mathrm{CO}_{2}$ from the atmosphere in the chemical systems: liquid systems (liquid solvents) and solid systems (solid sorbents) direct air capture. In the cryogenic processes, $\mathrm{CO}_{2}$ is removed from the air by freezing as a by-product of cryogenic oxygen separation. Membranes are used to separate $\mathrm{CO}_{2}$ from the air and seawater. Chemical systems are the preferred processes of DAC used by companies.

Liquid systems pass air through chemical solutions, which removes the $\mathrm{CO}_{2}$ while returning the rest of the air to the environment. For example, a typical process used is when sodium hydroxide is the solvent applied (used in the pulp and paper industry). $\mathrm{CO}_{2}$ reacts with sodium hydroxide $(\mathrm{NaOH})$ and precipitates sodium carbonate $\left(\mathrm{Na}_{2} \mathrm{CO}_{3}\right)$, which produces a highly pure gaseous $\mathrm{CO}_{2}$ stream when heated; after that, sodium hydroxide is recycled from sodium carbonate.

The reaction occurs between $\mathrm{NaOH}$ and $\mathrm{CO}_{2}$, as presented in Equation (2):

$$
\begin{gathered}
2 \mathrm{NaOH} \text { (solution) }+\mathrm{CO}_{2} \rightarrow \mathrm{Na}_{2} \mathrm{CO}_{3} \text { (solution) }+\mathrm{H}_{2} \mathrm{O} \\
\Delta \mathrm{H}=-105 \mathrm{~kJ} / \mathrm{mol}
\end{gathered}
$$

This process has a high potential to obtain high loadings of $\mathrm{CO}_{2}$ over a wide range of operating conditions and system designs because of the strong binding energy associated with the reaction presented in Equation (2). A disadvantage is the high energy requirements for releasing the $\mathrm{CO}_{2}$ during the regeneration stage [20].

Figure 11 shows a brief scheme of this process.

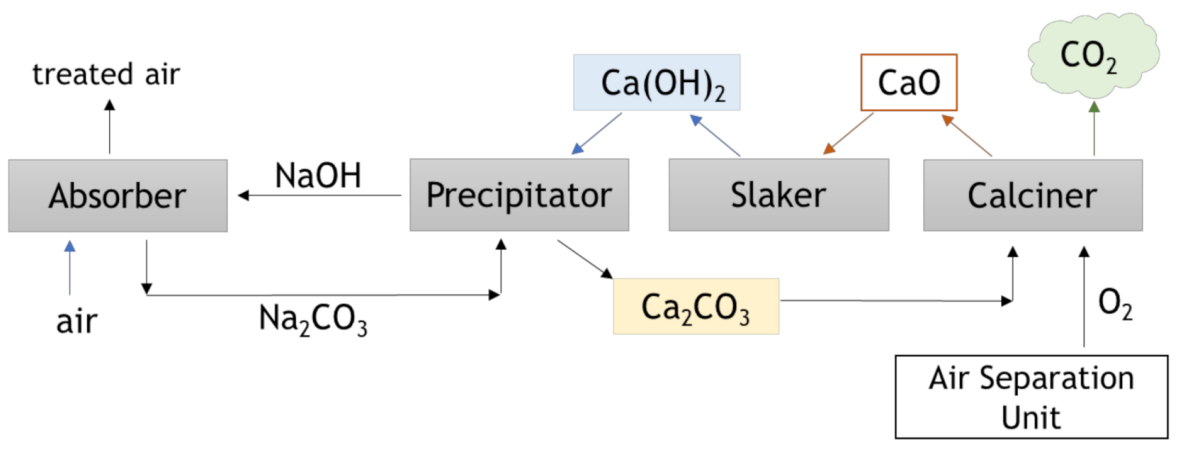

Figure 11. Brief scheme of a liquid solvent process used for capturing $\mathrm{CO}_{2}$ from air, using $\mathrm{NaOH}$ as the absorber (adapted from Mazzotti et al. [71]).

Solid direct air capture technology makes use of solid sorbent filters that chemically bind with $\mathrm{CO}_{2}$. When the filters are heated, they release the concentrated $\mathrm{CO}_{2}$, which can be captured for sequestration or utilization.

However, $\mathrm{CO}_{2}$ in the air is approximately 300 times ( 400 ppm) more dilute than in flue gas from a coal-fired power plant, which results in a costly process to separate $\mathrm{CO}_{2}$ with the same end purity as the one obtained in the $\mathrm{CO}_{2}$ captured from fossil fuel power plants [72]. Figure 12 shows a brief scheme of the DAC process.

At present, few companies are involved in the DAC field, all designing or using different technologies of DAC, and different markets are focused. 


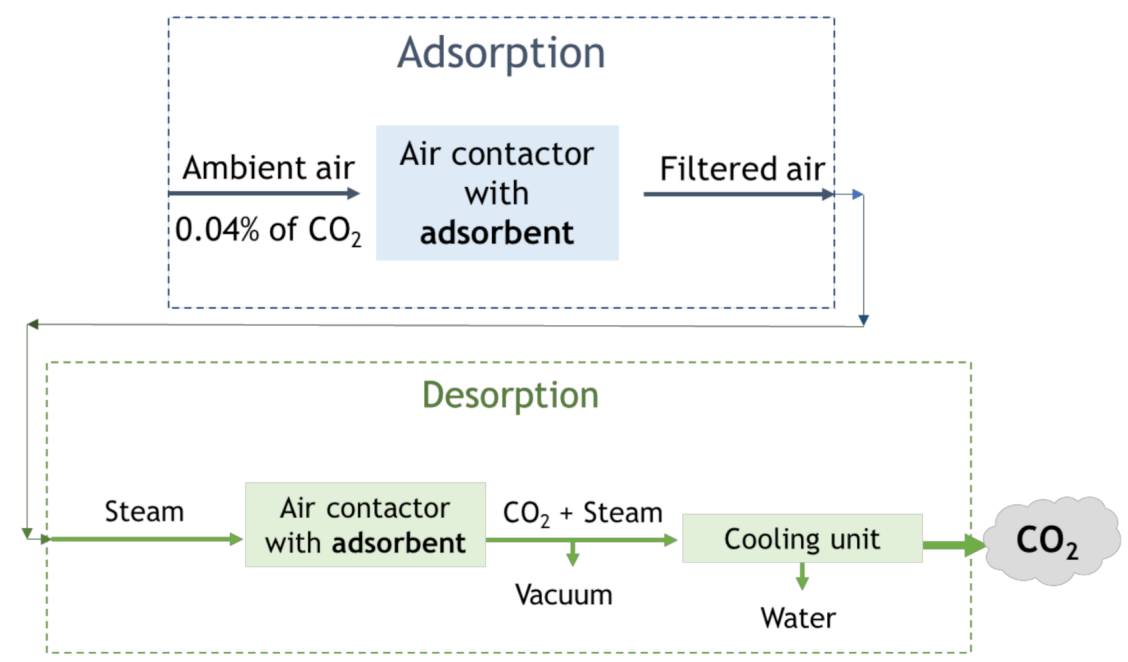

Figure 12. Schematic representation of the DAC process (adapted from Sinha and Realff [73]).

Carbon Engineering Ltd. (CE, Vancouver, BC, Canada) uses liquid alkali metal oxide sorbents regenerated by heat at around $800{ }^{\circ} \mathrm{C}$. CE uses natural gas to power its machines, co-capturing $\mathrm{CO}_{2}$ from the flue gas stream of the burned natural gas in addition to atmospheric capture [74,75].

Global Thermostat (GT, New York, NY, USA) is a US company which uses a solid amine-based sorbent material for $\mathrm{CO}_{2}$ capture from air, regenerated at around 80-100 ${ }^{\circ} \mathrm{C}$ [76].

Also, using DAC design, Climeworks AG (Zurich, Switzerland) capture $\mathrm{CO}_{2}$ with a system based on an adsorption-desorption process with alkaline-functionalized adsorbents. The adsorption is performed at ambient conditions while the desorption occurs using a temperature-vacuum-swing (TVSA) process. The pressure decrease and the temperature increase from 80 to $120{ }^{\circ} \mathrm{C}$, allow to release the $\mathrm{CO}_{2}$ [76]. The enriched stream of $\mathrm{CO}_{2}$ is produced at 1 bar with a purity of $>99.8 \%$. If the relative humidity on the feed is high, the $\mathrm{H}_{2} \mathrm{O}$ is also extracted from the air as a by-product [77]. The first commercial DAC plant was presented in 2017 in Switzerland from Climeworks, with a capacity for $900 \mathrm{t}$ of $\mathrm{CO}_{2}$ captured per year from the air.

Currently, in Europe, in the United States (US), and in Canada, there are more than 15 DAC plants operating worldwide, most of them are small and sell $\mathrm{CO}_{2}$ captured for use (in carbonated drinks, for example). However, the first large-scale DAC plant has been developed in the US by a Carbon Engineering Ltd. and Occidental Petroleum partnership. The plant will capture up to $1 \mathrm{MtCO}_{2}$ (metric tonnes of $\mathrm{CO}_{2}$ ) per year for EOR. This unit could become operational as early as 2023 [76]. Table 4 presents the companies that are working to commercialize DAC systems nowadays.

Several studies have been presented with direct air capture applications to obtain climate change mitigation, some more optimistic than others. Creutzig, et al. [78] estimates that DAC will reach $1 \mathrm{Gt}$ of $\mathrm{CO}_{2}$ per year in 2050. Fasihi, et al. [79] presents an estimative of about $7 \mathrm{Gt}$ of $\mathrm{CO}_{2}$ captured per year in the energy system, and about $8 \mathrm{Gt}$ of $\mathrm{CO}_{2}$ captured per year in carbon dioxide removal in the same year.

Today, the costs involved in direct air capture systems are approximately $510 €$ per tonnes of $\mathrm{CO}_{2}$ captured [80].

The transition to a net-zero energy system, in which the amount of $\mathrm{CO}_{2}$ released to the atmosphere is equivalent to the amount being removed, is highly dependent on the carbon removal processes. The application of decarbonization strategies in the several sectors as aviation and heavy industry would be very difficult. In these cases, carbon removal technologies can be the key for an effective transition. In the 2030 Sustainable Development Scenario, it was defined that $\mathrm{CO}_{2}$ capture by direct air capture should reach almost $10 \mathrm{Mt}$ of $\mathrm{CO}_{2}$ per year (in 2030) [76]. 
Table 4. Companies Working to Commercialize Systems of Direct Air Capture technology [72].

\begin{tabular}{|c|c|c|c|c|c|}
\hline Company & Type of System & Type of Technology & $\begin{array}{c}\text { Type of } \\
\text { Regeneration }\end{array}$ & $\begin{array}{c}\text { Purity/ } \\
\text { Application }\end{array}$ & Scale \\
\hline $\begin{array}{c}\text { Carbon } \\
\text { Engineering Ltd. }\end{array}$ & Liquid solvent & $\begin{array}{l}\text { Potassium hydroxide } \\
\text { solution/calcium } \\
\text { carbonation }\end{array}$ & Temperature & $99 \%$ & $\begin{array}{c}\text { Pilot } \\
1 \text { tonne per day }\end{array}$ \\
\hline Climeworks & Solid sorbent & $\begin{array}{l}\text { Amine-functionalized } \\
\text { filter }\end{array}$ & $\begin{array}{l}\text { Temperature or } \\
\text { vacuum }\end{array}$ & $\begin{array}{l}99 \% \text { w / dilution } \\
\text { depending on the } \\
\text { application }\end{array}$ & $\begin{array}{l}\text { Demonstration } \\
900 \text { tonne per year }\end{array}$ \\
\hline $\begin{array}{c}\text { Global } \\
\text { Thermostat }\end{array}$ & Solid sorbent & $\begin{array}{l}\text { Amine-modified } \\
\text { monolith }\end{array}$ & $\begin{array}{c}\text { Temperature } \\
\text { and/or vacuum }\end{array}$ & $99 \%$ & $\begin{array}{l}1000 \text { tonne } \\
\text { per year }\end{array}$ \\
\hline Infinitree & Solid sorbent & Ion-exchange sorbent & Humidity & $3-5 \%$ algae & Laboratory \\
\hline Skytree & Solid sorbent & $\begin{array}{l}\text { Porous plastic beads } \\
\text { functionalized with } \\
\text { benzylamines }\end{array}$ & Temperature & $\begin{array}{l}\text { Air purification, } \\
\text { greenhouses }\end{array}$ & Appliance \\
\hline
\end{tabular}

\section{Industrial Processes}

Industrial processes are responsible for raw materials conversion into useable products, which results in energy consumption and $\mathrm{CO}_{2}$ emissions. For this conversion, fossil fuels continue to satisfy most of the industrial energy demand. However, these processes can be transformed to meet global climate changes. The industrial $\mathrm{CO}_{2}$ emissions can be categorized into four main groups [27]:

- Energy-related emissions: combustion of coal, oil, and natural gas (considering biomass with an emission factor of zero);

- Process emissions: associated with chemical and physical reactions, such as the production of aluminum, ferroalloys, lubricants and paraffins, and fuels through coal and gas-to-liquid processes, etc.;

- Direct emissions: all emissions associated with industrial processes, except the electricity, heat, and steam purchases (energy-related emissions plus process emissions);

- Indirect emissions: all emissions "out of the facilities", including electricity, heat and steam purchased.

Industry is responsible for about one-quarter of $\mathrm{CO}_{2}$ emissions from energy and industrial processes, being $90 \%$ of the direct GHG emissions from industrial production, and $40 \%$ of global energy demand, especially in cement, in iron and steel and in chemicals industries, which are the most challenging for emissions reduction. Between 1990 and 2017, industrial $\mathrm{CO}_{2}$ emissions increased $70 \%$. According to Clean Technology Scenario (CTS), consistent with the Paris Agreement defined targets, more than $28 \mathrm{Gt}$ of $\mathrm{CO}_{2}$ must be captured from industrial facilities until 2060 [27]. CCUS can be a critical factor in the industry decarbonization action. CCUS technologies will contribute to a reduction of $21 \mathrm{Gt}$ of $\mathrm{CO}_{2}$ of emissions (27\%) in the period of 2017-2060, from the cement (18\%, capturing $5 \mathrm{Gt}$ of $\left.\mathrm{CO}_{2}\right)$, iron and steel $\left(15 \%\right.$, capturing $10 \mathrm{Gt}$ of $\left.\mathrm{CO}_{2}\right)$, and chemical subsectors $(38 \%$, capturing $14 \mathrm{Gt}$ of $\mathrm{CO}_{2}$ ) [27].

Several industrial sectors produce $\mathrm{CO}_{2}$ at different temperatures, concentrations, purities, pressures, and volumes, and for all of them, carbon dioxide capture technologies could be applicable. This will be vital for energy-intensive industries, such as those listed below to capture carbon if the EU is to reach its climate targets. These industry subsectors consider iron and steel, chemicals and petrochemicals, cement, pulp and paper, aluminium, and other industries such as ceramics and glass production.

The costs involved in $\mathrm{CO}_{2}$ capture vary greatly by point source and by capture technology. Costs range from 15 USD per tonne of carbon dioxide (USD/t of $\mathrm{CO}_{2}$ ) to $60 \mathrm{USD} / \mathrm{t}$ of $\mathrm{CO}_{2}$ for concentrated $\mathrm{CO}_{2}$ streams (e.g., natural gas processing and bioethanol production through fermentation), or from $40 \mathrm{USD} / \mathrm{tCO}_{2}$ to $80 \mathrm{USD} / \mathrm{tCO}_{2}$ for coal- and gas-fired power plants. The costs can be over USD $100 / \mathrm{t}$ of $\mathrm{CO}_{2}$ for smaller or more dilute point sources (e.g., industrial furnaces) [27]. 
The current status of industrial sectors is encouraging. Several works are in development today, especially involving the $\mathrm{CO}_{2}$ capture from high -purity $\mathrm{CO}_{2}$ sources.

\title{
6. Conclusions
}

International climate obligations, especially the values established in the Paris Agreement, require detailed monitoring and reporting of greenhouse gas emissions, which allowed to observe the increase of $\mathrm{CO}_{2}$ emissions over time. These scary numbers allow understanding the immediate need to act to reduce the emissions. In this regard, $\mathrm{CO}_{2}$ capture, utilization, and storage have demonstrated a high potential to be used to reduce global warming potential from power plants. CCS/CCUS has many challenges to overcome. For that, continuous advancement of knowledge is essential to improve the economic and environmental feasibility and technologies potential. As can be seen, several projects are under study to improve the capture of $\mathrm{CO}_{2}$ and utilization/storage. In the future, some technologies may offer a range of potential opportunities for a sustainable global industry, supporting the climate change objectives, the circular economy, renewable energy deployment, the evolution of $\mathrm{CO}_{2}$ capture systems, among others. With the $1.5^{\circ} \mathrm{C}$ pathway of the Paris Agreement, $\mathrm{CO}_{2}$ emissions should be 0 in 2050. Therefore, there is still a long path ahead.

Author Contributions: Conceptualization, M.J.R.; Writing—original draft preparation, M.J.R.; Writingreview and editing, M.J.R., A.P., A.F.P.F., A.M.R. and A.E.R.; Visualization, M.J.R.; Supervision, A.F.P.F., A.M.R. and A.E.R. All authors have read and agreed to the published version of the manuscript.

Funding: This work was financially supported by: Base Funding-UIDB/50020/2020 of the Associate Laboratory LSRE-LCM-funded by national funds through FCT/MCTES (PIDDAC). Financial support o NORTE-01-0145-FEDER-000006f FCT-Fundação para a Ciência e Tecnologia under CEEC Institucional program is also acknowledged.

Institutional Review Board Statement: Not applicable.

Informed Consent Statement: Informed consent was obtained from all subjects involved in the study.

Conflicts of Interest: No conflict of interest.

\author{
Nomenclature \\ AMP 2-Amino-2-methyl-1-propanol \\ BECCS Bioenergy with Carbon Capture and Storage \\ CCS Carbon Capture and Storage \\ CCU Carbon Capture and Utilization \\ CCUS Carbon Capture, Utilization, and Storage \\ DAC Direct Air Capture \\ DEA Diethanolamine \\ EGR Enhanced Gas Recovery \\ EOR Enhanced Oil Recovery \\ ESA Electrical Swing Adsorption \\ HBCC Hydrate-based Carbon Dioxide Capture \\ IGCC Integrated Gasification Combined Cycle \\ MDEA Methyl diethanolamine \\ MEA Monoethanolamine \\ PSA Pressure Swing Adsorption \\ TSA Temperature Swing Adsorption \\ TVSA Temperature-Vacuum Swing Adsorption
}




\section{Appendix A}

Table A1. Summary of other CCS facilities that are working in Europe.

\begin{tabular}{|c|c|c|c|c|c|}
\hline Name & Status & Country & Data & Industry & Observations \\
\hline $\begin{array}{c}\text { CATO } \\
\text { Programme }\end{array}$ & $\mathrm{O}$ & $\begin{array}{l}\text { The } \\
\text { Netherlands }\end{array}$ & 2004 & Various & $\begin{array}{l}\text { Responsible for covering the full CCS chain and } \\
\text { addressing both fundamental and applied topics } \\
\text { including regulation and safety and public perception }\end{array}$ \\
\hline $\begin{array}{c}\mathrm{CO}_{2} \text { FieldLab } \\
\text { Project }\end{array}$ & $\mathrm{C}$ & Norway & - & $\mathrm{N} / \mathrm{A}$ & $\begin{array}{l}\text { Project is led by Sintef Petroleum Research, with the } \\
\text { purpose of testing the sensitivity of a variety of } \\
\text { monitoring systems by observing the migration of small } \\
\text { amounts of injected } \mathrm{CO}_{2} \text { in the shallow subsurface }\end{array}$ \\
\hline $\begin{array}{l}\mathrm{CO}_{2} \text { MultiStore } \\
\text { Joint Industrial } \\
\text { Project (JIP) }\end{array}$ & $\mathrm{C}$ & UK & 2012 & $\mathrm{~N} / \mathrm{A}$ & $\begin{array}{l}\text { Project is led by Scottish Carbon Capture and Storage } \\
\text { with joint funding and expert support from CCS project } \\
\text { developers and public corporations, to support the } \\
\text { development of multi-use regional } \mathrm{CO}_{2} \text { storage assets }\end{array}$ \\
\hline $\begin{array}{l}\text { Hisarma Pilot } \\
\text { Plant (Reducing } \\
\mathrm{CO}_{2} \text { Emissions } \\
\text { in Steelmaking) }\end{array}$ & $\mathrm{O}$ & $\begin{array}{l}\text { The } \\
\text { Netherlands }\end{array}$ & 2007 & $\begin{array}{l}\text { Iron and } \\
\quad \text { Steel } \\
\text { Production }\end{array}$ & $\begin{array}{l}\text { A coal-based Hisarna smelting reduction process in } \\
\text { steelmaking industry was developed by Tata Steel, Rio } \\
\text { Tinto and ULCOS partners, and it has been operational } \\
\text { since } 2011 . \mathrm{CO}_{2} \text { emissions were reduced by } 20 \% \text {, and } \\
\text { can be } 80 \% \text { lower when CCS is applied }\end{array}$ \\
\hline QICS Project & C & UK & 2010 & $\mathrm{~N} / \mathrm{A}$ & $\begin{array}{l}\text { Project led by the Plymouth Marine Laboratory, to } \\
\text { quantify and monitor Environmental Impacts of } \\
\text { Geological Carbon Storage involved in the assessment } \\
\text { and monitoring of the first controlled release of } \mathrm{CO}_{2} \\
\text { into seaed sediments }\end{array}$ \\
\hline
\end{tabular}

Table A2. Summary of pilot and demonstration mode CCS facilities in Europe.

\begin{tabular}{|c|c|c|c|c|c|}
\hline Name & Status & Country & Data & Industry & Observations \\
\hline $\begin{array}{l}\text { ELCOGAS } \\
\text { Pre-combustion } \\
\text { Carbon Capture } \\
\text { Pilot Project: } \\
\text { Puertollano }\end{array}$ & $\mathrm{C}$ & Spain & 2010 & $\begin{array}{c}\text { Power } \\
\text { Generation }\end{array}$ & $\begin{array}{l}\text { A pilot plant was integrated into the Puertollano } \\
\text { IGCC plant in Spain to test the feasibility of } \\
\text { pre-combustion technology to capture } \mathrm{CO}_{2} \text { in an } \\
\text { IGCC environment that uses solid fossil fuels and } \\
\text { wastes as feedstock; operational tests } \\
\text { occurred in } 2010 / 2011\end{array}$ \\
\hline $\begin{array}{l}\text { Aberthaw Pilot } \\
\text { Carbon Capture } \\
\text { Facility }\end{array}$ & C & UK & 2013 & $\begin{array}{c}\text { Power } \\
\text { generation }\end{array}$ & $\begin{array}{l}\text { A pilot-scale plant at the Aberthaw power station } \\
\text { in South Wales UK tested the Cansolv integrated } \\
\mathrm{CO}_{2} \text { and } \mathrm{SO}_{2} \text { removal system during } 2013 / 2014\end{array}$ \\
\hline $\begin{array}{l}\text { Abu Dhabi CCS } \\
\text { (Phase } 1 \text { being } \\
\text { Enirates Steel } \\
\text { Industries) }\end{array}$ & $\mathrm{O}$ & $\begin{array}{l}\text { United Arab } \\
\text { Emirates }\end{array}$ & 2016 & $\begin{array}{l}\text { Iron and Steel } \\
\text { Production }\end{array}$ & $\begin{array}{l}\text { First fully commercial CCS facility in the iron and } \\
\text { steel industry, and involves the } \mathrm{CO}_{2} \text { capture via a } \\
\text { new build } \mathrm{CO}_{2} \text { Compression facility using high } \\
\text { purity } \mathrm{CO}_{2} \text { produced as a by-product of the direct } \\
\text { reduced iron-making process at the Emirates Steel } \\
\text { Industries factory in Mussafah. The compression } \\
\text { facility has a capture capacity of } 0.8 \mathrm{Mtpa} \text {. The } \\
\mathrm{CO}_{2} \text { is captured and is transported via pipeline to } \\
\text { Abu Dhabi National Oil Company ADNOC oil } \\
\text { reservoirs for EOR }\end{array}$ \\
\hline $\begin{array}{l}\text { Acorn (Minimum } \\
\text { Viable CCS } \\
\text { Development) }\end{array}$ & $\mathrm{AD}$ & $\begin{array}{l}\text { United } \\
\text { Kingdom }\end{array}$ & 2021-2022 & Various & $\begin{array}{l}\text { Initiate a low cost full chain CCS project in the } \\
\text { North East of Scotland; cluster of capture, } \\
\text { transport and storage infrastructure; } \mathrm{CO}_{2} \text { is } \\
\text { separated from natural gas and vented, adjacent to } \\
\text { an offshore transport pipeline, which connects to a } \\
\text { well understood offshore basin, rich in } \\
\text { storage opportunities }\end{array}$ \\
\hline
\end{tabular}


Table A2. Cont.

\begin{tabular}{|c|c|c|c|c|c|}
\hline Name & Status & Country & Data & Industry & Observations \\
\hline $\begin{array}{c}\text { Brindisi } \mathrm{CO}_{2} \\
\text { Capture Pilot Plant }\end{array}$ & C & Italy & 2010 & $\begin{array}{c}\text { Power } \\
\text { Generation }\end{array}$ & $\begin{array}{l}\text { A pilot-scale plant at the Brindisi power plant in } \\
\text { south-eastern Italy tested a number of solvent } \\
\text { technologies during } 2010-2012\end{array}$ \\
\hline $\begin{array}{l}\text { Buggenum Carbon } \\
\text { Capture }\left(\mathrm{CO}_{2}\right. \\
\text { Catch-up) } \\
\text { Pilot Project }\end{array}$ & $\mathrm{C}$ & $\begin{array}{l}\text { The } \\
\text { Netherlands }\end{array}$ & 2011 & $\begin{array}{c}\text { Power } \\
\text { Generation }\end{array}$ & $\begin{array}{c}\text { A pilot-scale plant at the Willem-Alexander power } \\
\text { plant in The Netherlands (now closed) undertook } \\
\text { a } \mathrm{CO}_{2} \text { capture testing and R\&D program } \\
\text { between } 2011 \text { and } 2013\end{array}$ \\
\hline $\begin{array}{c}\text { C2A2 Field } \\
\text { Pilot-Le Havre }\end{array}$ & C & France & 2013 & $\begin{array}{c}\text { Power } \\
\text { Generation }\end{array}$ & $\begin{array}{l}\text { A pilot-scale plant at the Le Havre power plant in } \\
\text { France tested a specific carbon capture technology } \\
\text { during parts of } 2013 \text { and } 2014\end{array}$ \\
\hline CarbFix Project & $\mathrm{O}$ & Iceland & 2012 & $\begin{array}{c}\text { Power } \\
\text { Generation }\end{array}$ & $\begin{array}{c}\text { Study of injection of pure } \mathrm{CO}_{2} \text { and a gas mixture } \\
\text { of } \mathrm{CO}_{2} \text { and } \mathrm{H} 2 \mathrm{~S} \text {, dissolved in water, into basaltic } \\
\text { formations; pilot tests in } 2012 \text { injected over } \\
200 \text { tonnes of } \mathrm{CO}_{2} \text { from a geothermal power plant }\end{array}$ \\
\hline CASTOR & $\mathrm{C}$ & Denmark & 2006 & $\begin{array}{c}\text { Power } \\
\text { Generation }\end{array}$ & $\begin{array}{c}\text { Tests of three solvents in a post-combustion pilot } \\
\text { plant located at the coal-fired Esbjerg power } \\
\text { plant in Denmark }\end{array}$ \\
\hline CEMCAP & $\mathrm{C}$ & Norway & 2015 & $\begin{array}{l}\text { Cement } \\
\text { Production }\end{array}$ & $\begin{array}{l}\text { Prepare the ground for large-scale implementation } \\
\text { of } \mathrm{CO}_{2} \text { capture in the European cement industry; } \\
\text { designed to strengthen and complement the } \\
\text { Norcem and ECRA CCS projects; technical } \\
\text { development, including technology demonstration } \\
\text { in a simulated industrial environment. }\end{array}$ \\
\hline CESAR & C & Denmark & 2008 & $\begin{array}{c}\text { Power } \\
\text { Generation }\end{array}$ & $\begin{array}{l}\text { Project for the post-combustion capture work } \\
\text { undertaken at the coal-fired Esbjerg pilot plant in } \\
\text { Denmark under the CASTOR project; } \\
\text { modifications to the Esbjerg pilot plant were } \\
\text { undertaken during 2008, after which a three test } \\
\text { campaign was conducted covering a benchmark } \\
\text { and two novel solvents }\end{array}$ \\
\hline $\begin{array}{c}\text { CIUDEN: } \mathrm{CO}_{2} \\
\text { Capture \& } \\
\text { Transport } \\
\text { Technology } \\
\text { Development Plant }\end{array}$ & C & Spain & 2012 & $\begin{array}{c}\text { Power } \\
\text { Generation }\end{array}$ & $\begin{array}{c}\text { The Hontomin Technology Development } \\
\text { Plant- } \mathrm{CO}_{2} \text { Capture \& Transport the CIUDEN } \\
\text { Technology Development Center, successfully } \\
\text { completed the full } \mathrm{CO}_{2} \text { capture process, using } \\
\text { oxy-combustion in the circulating fluidized bed } \\
\text { CFB boiler with the compression } \\
\text { and purification unit }\end{array}$ \\
\hline $\begin{array}{c}\text { CIUDEN: } \mathrm{CO}_{2} \\
\text { Storage } \\
\text { Technology } \\
\text { Development Plant }\end{array}$ & $\mathrm{O}$ & Spain & 2015 & $\mathrm{~N} / \mathrm{A}$ & $\begin{array}{l}\text { The Hontomin Storage Technology Development } \\
\text { Plant- the site includes one injection well and a } \\
\text { monitoring well;10,000 tonnes of } \mathrm{CO}_{2} \text { are planned } \\
\text { to be injected in the period } 2017-2020\end{array}$ \\
\hline $\begin{array}{l}\mathrm{CO}_{2} \text { Capture Test } \\
\text { Facility at } \\
\text { Norcem Brevik }\end{array}$ & $\mathrm{C}$ & Norway & 2013 & $\begin{array}{l}\text { Cement } \\
\text { Production }\end{array}$ & $\begin{array}{l}\text { A real cement flue gas at the Brevik plant in } \\
\text { Norway was used to test three different } \\
\text { post-combustion technologies, while } \\
\text { investigations on a fourth technology were } \\
\text { performed offsite based on a pilot installed at } \\
\text { Stuttgart University; tests were done from } 2013 \text { to } \\
2017 \text { and aimed to demonstrate the } \mathrm{CO}_{2} \text { capture } \\
\text { from a cement plant, to improve understanding of } \\
\text { these technologies for large-scale application }\end{array}$ \\
\hline $\begin{array}{l}\text { DMX }^{\mathrm{TM}} \\
\text { Demonstration in } \\
\text { Dunkirk }\end{array}$ & $\mathrm{AD}$ & France & 2022 & $\begin{array}{l}\text { Iron and Steel } \\
\text { Production }\end{array}$ & $\begin{array}{l}\text { Designed by Axens, started in } 2020 \text { at the } \\
\text { ArcelorMittal steelworks site in Dunkirk; able to } \\
\text { capture } 0.5 \text { metric tonnes of } \mathrm{CO}_{2} \text { an hour from } \\
\text { steelmaking gases by } 2022\end{array}$ \\
\hline
\end{tabular}


Table A2. Cont.

\begin{tabular}{|c|c|c|c|c|c|}
\hline Name & Status & Country & Data & Industry & Observations \\
\hline $\begin{array}{l}\text { Drax bioenergy } \\
\text { carbon capture } \\
\text { pilot plant }\end{array}$ & $\mathrm{O}$ & $\begin{array}{l}\text { United } \\
\text { Kingdom }\end{array}$ & 2019 & $\begin{array}{c}\text { Power } \\
\text { Generation }\end{array}$ & $\begin{array}{c}\text { The } \mathrm{CO}_{2} \text { capture pilot plant captures } 1 \text { tpd from } \\
\text { the Drax power station unit, which runs } 100 \% \\
\text { biomass feedstock }\end{array}$ \\
\hline $\begin{array}{l}\text { ELCOGAS } \\
\text { Pre-combustion } \\
\text { Carbon Capture } \\
\text { Pilot Project: } \\
\text { Puertollano }\end{array}$ & $\mathrm{C}$ & Spain & 2010 & $\begin{array}{c}\text { Power } \\
\text { Generation }\end{array}$ & $\begin{array}{l}\text { A pilot plant was integrated into the Puertollano } \\
\text { IGCC plant in Spain to test the feasibility of } \\
\text { pre-combustion technology to capture } \mathrm{CO}_{2} \text { in an } \\
\text { IGCC environment that uses solid fossil fuels and } \\
\text { wastes as the main feedstock }\end{array}$ \\
\hline $\begin{array}{c}\text { Ferrybridge } \\
\text { Carbon Capture } \\
\text { Pilot (CCPilot100+) }\end{array}$ & C & $\begin{array}{l}\text { United } \\
\text { Kingdom }\end{array}$ & 2011 & $\begin{array}{c}\text { Power } \\
\text { Generation }\end{array}$ & $\begin{array}{l}\text { Involves the capture of } 100 \text { tpd of } \mathrm{CO}_{2} \text { from a flue } \\
\text { gas stream at the Ferrybridge power station; } \\
\text { designed to test the application of an amine-based, } \\
\text { post-combustion capture process under realistic } \\
\text { operating conditions }\end{array}$ \\
\hline $\begin{array}{l}\text { Geothermal Plant } \\
\text { with } \mathrm{CO}_{2} \\
\text { Re-injection }\end{array}$ & C & Croatia & 2018 & $\begin{array}{c}\text { Power } \\
\text { Generation }\end{array}$ & $\begin{array}{l}\text { A hybrid geothermal system is used, utilizing the } \\
\text { energy potential of hot brines with dissolved } \\
\text { natural gases to deliver combined heat and power } \\
\text { at its Draškovec development; is expected to } \\
\text { supply } 17-18 \mathrm{MW} \text { of power; } \mathrm{CO}_{2} \text { separation, } \\
\text { capture and injection capacity is at } \\
\text { around } 50,000 \text { tpa }\end{array}$ \\
\hline $\begin{array}{c}\mathrm{K} 12-\mathrm{B} \mathrm{CO}_{2} \\
\text { Injection Project }\end{array}$ & $\mathrm{C}$ & $\begin{array}{l}\text { The } \\
\text { Netherlands }\end{array}$ & 2004 & $\begin{array}{c}\text { Natural Gas } \\
\text { Processing }\end{array}$ & $\begin{array}{l}\mathrm{CO}_{2} \text { is captured at the offshore natural gas } \\
\text { production facility at the K12-B gas field and } \\
\text { injected back into the depleted gas reservoir; } \\
\text { cumulative injection in } 2017 \text { was } \\
\text { over 100,000 tonnes }\end{array}$ \\
\hline $\begin{array}{l}\text { Karlshamn } \\
\text { Field Pilot }\end{array}$ & $\mathrm{C}$ & Sweden & 2009 & $\begin{array}{c}\text { Power } \\
\text { Generation }\end{array}$ & $\begin{array}{c}\text { One of a number of test facilities used by Alstom } \\
\text { to test the viability of its Chilled Ammonia Process } \\
\text { for } \mathrm{CO}_{2} \text { capture and involved the capture of } \\
\text { around } 30 \text { tpd of } \mathrm{CO}_{2}\end{array}$ \\
\hline Ketzin Pilot Project & $\mathrm{C}$ & Germany & 2004 & $\begin{array}{l}\text { Power } \\
\text { Generation } \\
\text { and } \\
\text { Hydrogen } \\
\text { Production }\end{array}$ & $\begin{array}{l}\text { The first geological } \mathrm{CO}_{2} \text { storage project on the } \\
\text { European mainland and one of the largest storage } \\
\text { pilot projects in the world; constituted by three } \\
\text { phases, over } 67,000 \text { tonnes of } \mathrm{CO}_{2} \text { were injected } \\
\text { between } 2008 \text { and } 2013 \text {, and post-injection and site } \\
\text { behavior monitoring completed in } 2017\end{array}$ \\
\hline $\begin{array}{l}\text { La Pereda Calcium } \\
\text { Looping Pilot Plant }\end{array}$ & $\mathrm{C}$ & Spain & 2012 & $\begin{array}{c}\text { Power } \\
\text { Generation }\end{array}$ & $\begin{array}{c}\text { In operation in 2012, undertook three European } \\
\text { funded 'projects' or test campaigns, testing the } \\
\text { viability of post-combustion capture by calcium } \\
\text { looping, 1.7 MWth }\end{array}$ \\
\hline $\begin{array}{c}\text { Lacq CCS } \\
\text { Pilot Project }\end{array}$ & $\mathrm{C}$ & France & 2010 & $\begin{array}{c}\text { Power } \\
\text { Generation }\end{array}$ & $\begin{array}{l}\text { A storage-focused project of global significance } \\
\text { that injected } 51,000 \text { tonnes of } \mathrm{CO}_{2} \text { over a } 39 \text { month } \\
\text { period from } 2010 \text { to } 2013 \text {; including a } \\
\text { comprehensive monitoring plan }\end{array}$ \\
\hline $\begin{array}{l}\text { LEILAC-Low } \\
\text { Emissions } \\
\text { Intensity Lime and } \\
\text { Cement Project }\end{array}$ & In $C$ & Belgium & $2020^{\prime} \mathrm{s}$ & $\begin{array}{l}\text { Cement } \\
\text { Production }\end{array}$ & $\begin{array}{l}\text { Designed, built and operated a pilot plant to: } \\
\text { Direct Separation calcining technology can work at } \\
\text { the temperatures necessary to process limestone } \\
\text { for the lime and cement industries; capture over } \\
95 \% \text { of the } \mathrm{CO}_{2} \text { emissions from both industries } \\
\text { without significant energy or capital penalty }\end{array}$ \\
\hline $\begin{array}{l}\text { Renfrew Oxy-fuel } \\
\text { (Oxycoal 2) Project }\end{array}$ & C & $\begin{array}{l}\text { United } \\
\text { Kingdom }\end{array}$ & 2007 & $\begin{array}{c}\text { Power } \\
\text { Generation }\end{array}$ & $\begin{array}{l}\text { Consisted of an initial oxy-fuel technology } \\
\text { mapping phase followed by testing of a 40-MWth } \\
\text { oxy-fuel burner at Renfrew, Scotland, under } \\
\text { realistic operating conditions and included testing } \\
\text { adaptation from air-firing to oxy-fuel firing on } \\
\text { pulverized coal; the pilot facility } \\
\text { completed } 20 \text { test days }\end{array}$ \\
\hline
\end{tabular}


Table A2. Cont.

\begin{tabular}{|c|c|c|c|c|c|}
\hline Name & Status & Country & Data & Industry & Observations \\
\hline $\begin{array}{l}\text { Schwarze Pumpe } \\
\text { Oxy-fuel } \\
\text { Pilot Plant }\end{array}$ & C & Germany & 2008 & $\begin{array}{c}\text { Power } \\
\text { Generation }\end{array}$ & $\begin{array}{l}\text { The } 30 \text { MWth Schwarze Pumpe oxy-fuel pilot was } \\
\text { the world's first large-scale testing of the entire } \\
\text { oxy-fuel combustion technology chain; In 2014, it } \\
\text { was discontinued research into coal-fired power } \\
\text { with CCS; the pilot plant captured and liquefied } \\
11,000 \text { tonnes of } \mathrm{CO}_{2} \text {; Around } 1500 \text { tonnes of } \mathrm{CO}_{2} \\
\text { from the Schwarze Pumpe oxy-fuel capture pilot } \\
\text { plant were injected }\end{array}$ \\
\hline $\begin{array}{l}\text { STEPWISE Pilot of } \\
\text { SEWGS } \\
\text { Technology at } \\
\text { Swerea/Mefos }\end{array}$ & $\mathrm{O}$ & Sweden & 2017 & $\begin{array}{c}\text { Iron and Steel } \\
\text { Production }\end{array}$ & $\begin{array}{c}\text { The Sorption Enhanced Water Gas Shift reaction } \\
\text { SEWGS process is to be demonstrated at a } \mathrm{CO}_{2} \\
\text { capture rate of } 14 \text { tonnes per day; the pilot plant is } \\
\text { fed with blast furnace gas from the adjacent steel } \\
\text { plant of SSAB; the test facility was launched in } \\
\text { September } 2017\end{array}$ \\
\hline $\begin{array}{l}\text { Wilhelmshaven } \\
\mathrm{CO}_{2} \text { Capture } \\
\text { Pilot Plant }\end{array}$ & C & Germany & 2012 & $\begin{array}{c}\text { Power } \\
\text { Generation }\end{array}$ & $\begin{array}{l}\mathrm{CO}_{2} \text { capture from a side stream of the } \\
\text { Wilhelmshaven coal-fired power station; designed } \\
\text { to capture } 70 \text { tpd of } \mathrm{CO}_{2} \text { at full capacity; achieved } \\
4500 \mathrm{~h} \text { of operation in the first quarter of } 2014\end{array}$ \\
\hline
\end{tabular}

Table A3. Summary of CCS facility tests centers in Europe.

\begin{tabular}{|c|c|c|c|c|c|}
\hline Name & Status & Country & Data & Industry & Observations \\
\hline $\begin{array}{l}\text { Technology Centre } \\
\text { Mongstad (TCM) }\end{array}$ & $\mathrm{O}$ & Norway & 2012 & Oil Refining & $\begin{array}{l}\text { The demonstration test facility comprises two } \\
\text { capture units, one designed for amine-based } \\
\text { solvents and the other for chilled aqueous ammonia }\end{array}$ \\
\hline $\begin{array}{c}\text { UKCCSRC } \\
\text { Pilot-scale } \\
\text { Advanced Capture } \\
\text { Technology } \\
\text { (PACT) }\end{array}$ & $\mathrm{O}$ & $\begin{array}{l}\text { United } \\
\text { Kingdom }\end{array}$ & - & $\begin{array}{c}\text { Power } \\
\text { Generation }\end{array}$ & $\begin{array}{l}\text { PACT facilities bring together a range of integrated } \\
\text { pilot-scale and accompanying specialist research } \\
\text { and analytical facilities, supported by leading } \\
\text { academic expertise; post-combustion pilot is } \\
\text { installed and is jointly operated by the Universities } \\
\text { of Leeds and Sheffield }\end{array}$ \\
\hline
\end{tabular}

Table A4. Summary of $\mathrm{CO}_{2}$ utilization facilities in Europe.

\begin{tabular}{|c|c|c|c|c|c|}
\hline Name & Status & Country & Data & Industry & Observations \\
\hline $\begin{array}{c}\text { ArcelorMittal } \\
\text { Steelanol Ghent }\end{array}$ & In $C$ & Belgium & 2020 & $\begin{array}{l}\text { Iron and Steel } \\
\text { Production }\end{array}$ & $\begin{array}{c}\text { ArcelorMittal } \\
\text { Steelanol Ghent }\end{array}$ \\
\hline $\begin{array}{c}\text { Port Jérôme } \mathrm{CO}_{2} \\
\text { Capture Plant }\end{array}$ & $\mathrm{O}$ & France & 2015 & $\begin{array}{l}\text { Hydrogen } \\
\text { Production }\end{array}$ & $\begin{array}{c}\text { Port Jérôme } \mathrm{CO}_{2} \\
\text { Capture Plant }\end{array}$ \\
\hline $\begin{array}{c}\text { Twence Waste-to-energy } \\
\mathrm{CO}_{2} \text { Capture } \\
\text { and Utilisation }\end{array}$ & $\mathrm{O}$ & The Netherlands & 2014 & Waste Incineration & $\begin{array}{c}\text { Twence Waste-to-energy } \\
\mathrm{CO}_{2} \text { Capture } \\
\text { and Utilisation } \\
\end{array}$ \\
\hline
\end{tabular}

\section{References}

1. Climate Change Service. Surface Air Temperature for September 2019. Available online: https://climate.copernicus.eu/surfaceair-temperature-september-2019 (accessed on 14 March 2021).

2. Borowski, P.F. Nexus between water, energy, food and climate change as challenges facing the modern global, European and Polish economy. AIMS Geosci. 2020, 6, 397-421. [CrossRef]

3. Folger, P. Carbon Capture: A Technology Assesssment; Congressional Research Service: Washington, DC, USA, 2013 ; p. 3.

4. Lallanilla, M. Greenhouse Gas Emissions: Causes \& Sources. Available online: http://www.livescience.com/37821-greenhousegases.html (accessed on 26 May 2016).

5. Jefferson, M. Energy policies for sustainable development. In World Energy Assessment: Energy and the Challenge of Sustainability; Communications Development Incorporated: Washington, DC, USA, 2000.

6. Green, C.; Byrne, K. Biomass: Impact on Carbon Cycle and Greenhouse Gas Emissions. Encycl. Energy 2004, 1, 223-236. [CrossRef]

7. Quadrelli, R.; Peterson, S. The energy-climate challenge: Recent trends in $\mathrm{CO}_{2}$ emissions from fuel combustion. Energy Policy 2007, 35, 5938-5952. [CrossRef] 
8. Olajire, A.A. $\mathrm{CO}_{2}$ capture and separation technologies for end-of-pipe applications-A review. Energy 2010, 35, 2610-2628. [CrossRef]

9. Masson-Delmotte, V. Global Warming of $1.5^{\circ}$ C.; IPCC - Intergovernmental Panel on Climate Change: Geneva, Switzerland, 2019; ISBN 978-92-9169-153-1.

10. Masson-Delmotte, V.P.; Zhai, H.-O.; Pörtner, D.; Roberts, J.; Skea, P.R.; Shukla, A.; Pirani, W.; Moufouma-Okia, C.; Péan, R.; Pidcock, S.; et al. Global Warming of $1.5^{\circ} \mathrm{C}$. An IPCC Special Report on the Impacts of Global Warming of $1.5^{\circ} \mathrm{C}$ above Pre-Industrial Levels and Related Global Greenhouse Gas Emission Pathways, in the Context of Strengthening the Global Response to the Threat of Climate Change, Sustainable Development, and Efforts to Eradicate Poverty; IPCC: Geneva, Switzerland, 2018.

11. Foley, A.; Smyth, B.M.; Pukšec, T.; Markovska, N.; Duić, N. A review of developments in technologies and research that have had a direct measurable impact on sustainability considering the Paris agreement on climate change. Renew. Sustain. Energy Rev. 2017, 68, 835-839. [CrossRef]

12. Sekera, J.; Lichtenberger, A. Assessing Carbon Capture: Public Policy, Science, and Societal Need. Biophys. Econ. Sustain. 2020, 5, 14. [CrossRef]

13. Bui, M.; Adjiman, C.S.; Bardow, A.; Anthony, E.J.; Boston, A.; Brown, S.; Fennell, P.S.; Fuss, S.; Galindo, A.; Hackett, L.A.; et al. Carbon capture and storage (CCS): The way forward. Energy Environ. Sci. 2018, 11, 1062-1176. [CrossRef]

14. Consoli, C. Bioenergy and Carbon Capture and Storage; Global CCS Institute: Docklands, Australia, 2019.

15. International Energy Agency. Global Emissions in 2019. Available online: https://www.iea.org/articles/global-co2-emissionsin-2019 (accessed on 18 March 2021).

16. International Energy Agency. Global Energy Review 2020; International Energy Agency: Paris, France, 2020. Available online: https:/ / www.iea.org/reports/global-energy-review-2020 (accessed on 18 March 2021).

17. Tiseo, I. Global Distribution of $\mathrm{CO}_{2}$ Emissions from Fossil Fuel and Cement by Sector 2020. Available online: https://www. statista.com/statistics/1129656/global-share-of-co2-emissions-from-fossil-fuel-and-cement/ (accessed on 18 March 2021).

18. Climate Action Tracker. 2100 Warming Projections. Available online: https://climateactiontracker.org/global/temperatures/ (accessed on 18 April 2021).

19. CarbonBrief-Clear on Climate. Explainer: The high-emissions 'RCP8.5' global warming scenario. Available online: https: //www.carbonbrief.org/explainer-the-high-emissions-rcp8-5-global-warming-scenario (accessed on 3 September 2020).

20. Pires, J.C.M.; Martins, F.G.; Alvim-Ferraz, M.C.M.; Simões, M. Recent developments on carbon capture and storage: An overview. Chem. Eng. Res. Des. 2011, 89, 1446-1460. [CrossRef]

21. Songolzadeh, M.; Ravanchi, M.T.; Soleimani, M. Carbon Dioxide Capture and Storage: A General Review on Adsorbents. World Acad. Sci. Eng. Technol. 2012, 6, 213-220.

22. International Energy Agency. Carbon Capture, Utilisation and Storage. Available online: https://www.iea.org/fuels-andtechnologies / carbon-capture-utilisation-and-storage (accessed on 3 August 2020).

23. Marocco Stuardi, F.; MacPherson, F.; Leclaire, J. Integrated $\mathrm{CO}_{2}$ capture and utilization: A priority research direction. Curr. Opin. Green Sustain. Chem. 2019, 16, 71-76. [CrossRef]

24. Romasheva, N.; Ilinova, A. CCS Projects: How Regulatory Framework Influences Their Deployment. Resources $2019,8,181$. [CrossRef]

25. Global CCS Institute. The Global Status of CCS; Summary report; Global Carbon Capture and Storage Institute Ltd.: Melbourne, Australia, 2015; Available online: https://www.globalccsinstitute.com/wp-content/uploads/2018/12/Global-Status-Report_20 15_Summary.pdf (accessed on 3 August 2020).

26. International Energy Agency. Energy Technology Perspectives; International Energy Agency: Paris, France, 2017. Available online: https:/ / www.iea.org/topics/energy-technology-perspectives (accessed on 18 March 2021).

27. International Energy Agency. Transforming Industry through CCUS. 2019. Available online: https://www.iea.org/reports/ transforming-industry-through-ccus (accessed on 18 March 2021).

28. Dindi, A.; Quang, D.V.; Vega, L.F.; Nashef, E.; Abu-Zahra, M.R.M. Applications of fly ash for $\mathrm{CO}_{2}$ capture, utilization, and storage. J. CO2 Util. 2019, 29, 82-102. [CrossRef]

29. IPCC. IPCC Special Report on Carbon Dioxide Capture and Storage; Prepared by Working Group III of the Intergovernmental Panel on Climate Change; Metz, B.O., Davidson, H.C., de Coninck, M.L., Meyer, L.A., Eds.; Cambridge University Press: Cambridge, UK; New York, NY, USA, 2005; p. 442.

30. Nota, G.; Nota, F.D.; Peluso, D.; Toro Lazo, A. Energy Efficiency in Industry 4.0: The Case of Batch Production Processes. Sustainability 2020, 12, 6631. [CrossRef]

31. Global CCS Institute. $\mathrm{CO}_{2}$ Capture Technologies; Global Carbon Capture and Storage Institute: Canberra, Australia, $2012 ; \mathrm{pp} .1-13$.

32. Pastor-Pérez, L.; Baibars, F.; Le Sache, E.; Arellano-García, H.; Gu, S.; Reina, T.R. $\mathrm{CO}_{2}$ valorisation via Reverse Water-Gas Shift reaction using advanced $\mathrm{Cs}$ doped $\mathrm{Fe}-\mathrm{Cu} / \mathrm{Al}_{2} \mathrm{O}_{3}$ catalysts. J. $\mathrm{CO}_{2}$ Util. 2017, 21, 423-428. [CrossRef]

33. Rackley, S.A. Carbon Capture from Power Generation, 2nd ed.; Carbon Capture and Storage; Elsevier: London, UK, 2017; ISBN 9780128120415.

34. U.S. Department Energy. Pre-Combustion $\mathrm{CO}_{2}$ Capture. Available online: https://www.energy.gov / fe/science-innovation/ carbon-capture-and-storage-research/carbon-capture-rd/pre-combustion-carbon (accessed on 15 August 2020).

35. National Energy Technology Laboratory Post-Combustion $\mathrm{CO}_{2}$ Capture. Available online: https://www.netl.doe.gov/coal/ carbon-capture/post-combustion (accessed on 1 April 2021). 
36. Buhre, B.J.P.; Elliott, L.K.; Sheng, C.D.; Gupta, R.P.; Wall, T.F. Oxy-fuel combustion technology for coal-fired power generation. Prog. Energy Combust. Sci. 2005, 31, 283-307. [CrossRef]

37. Wong, S. Module 3- $\mathrm{CO}_{2}$ Capture: Pre-Combustion (Decarbonisation) and Oxy-Fuel Technologies; Global CCS Institute: Docklands, VIC, Australia, 2011; Volume 1, pp. 45-54. Available online: https://www.globalccsinstitute.com/archive/hub/publications/11 4711/building-capacity-co2-capture-and-storage-apec-region (accessed on 3 August 2020).

38. Armstrong, K.; Styring, P. Assessing the Potential of Utilization and Storage Strategies for Post-Combustion $\mathrm{CO}_{2}$ Emissions Reduction. Front. Energy Res. 2015, 3. [CrossRef]

39. Bhown, A.S.; Freeman, B.C. Analysis and Status of Post-Combustion Carbon Dioxide Capture Technologies. Environ. Sci. Technol. 2011, 45, 8624-8632. [CrossRef]

40. Leung, D.Y.C.; Caramanna, G.; Maroto-Valer, M.M. An overview of current status of carbon dioxide capture and storage technologies. Renew. Sustain. Energy Rev. 2014, 39, 426-443. [CrossRef]

41. Luis, P. Use of monoethanolamine (MEA) for $\mathrm{CO}_{2}$ capture in a global scenario: Consequences and alternatives. Desalination 2016, 380, 93-99. [CrossRef]

42. Walspurger, S.; Van Dijk, H.A.J. EDGAR $\mathrm{CO}_{2}$ Purity: Type and Quantities of Impurities Related to CO2 Point Source and Capture Technology: A Literature Study; The Energy Research Centre of The Netherlands: Petten, The Netherlands, 2012.

43. Samanta, A.; Zhao, A.; Shimizu, G.K.H.; Sarkar, P.; Gupta, R. Post-Combustion $\mathrm{CO}_{2}$ Capture Using Solid Sorbents: A Review. Ind. Eng. Chem. Res. 2012, 51, 1438-1463. [CrossRef]

44. Grande, C.A. Advances in Pressure Swing Adsorption for Gas Separation. ISRN Chem. Eng. 2012, 2012, 13. [CrossRef]

45. Regufe, M.J.; Ribeiro, A.M.; Ferreira, A.F.P.; Rodrigues, A. $\mathrm{CO}_{2}$ Storage on Zeolites and Other Adsorbents. In Nanoporous Materials for Gas Storage; Kaneko, K., Rodríguez-Reinoso, F., Eds.; Springer: Singapore, 2019; pp. 359-381.

46. Yang, H.; Li, J.-R. Metal-Organic Frameworks (MOFs) for $\mathrm{CO}_{2}$ Capture. In Porous Materials for Carbon Dioxide Capture; Lu, A.-H., Dai, S., Eds.; Springer: Berlin/Heidelberg, Germany, 2014; pp. 79-113.

47. Regufe, M.J.; Tamajon, J.; Ribeiro, A.M.; Ferreira, A.; Lee, U.H.; Hwang, Y.K.; Chang, J.-S.; Serre, C.; Loureiro, J.M.; Rodrigues, A.E. Syngas Purification by Porous Amino-Functionalized Titanium Terephthalate MIL-125. Energy Fuels 2015, $29,4654-4664$. [CrossRef]

48. Lu, C.; Bai, H.; Wu, B.; Su, F.; Hwang, J.F. Comparative study of $\mathrm{CO}_{2}$ capture by carbon nanotubes, activated carbons, and zeolites Energy Fuels 2008, 22, 3050-3056. [CrossRef]

49. Regufe, M.J.; Ferreira, A.F.P.; Loureiro, J.M.; Rodrigues, A.; Ribeiro, A.M. Development of Hybrid Materials with Activated Carbon and Zeolite 13X for $\mathrm{CO}_{2}$ Capture from Flue Gases by Electric Swing Adsorption. Ind. Eng. Chem. Res. 2020, 59, 12197-12211. [CrossRef]

50. Regufe, M.J.; Ferreira, A.F.P.; Loureiro, J.M.; Rodrigues, A.; Ribeiro, A.M. Electrical conductive 3D-printed monolith adsorbent for $\mathrm{CO}_{2}$ capture. Microporous Mesoporous Mater. 2019, 278, 403-413. [CrossRef]

51. Clodic, D.; Younes, M. A new Method for CO2 Capture: Frosting CO2 at Atmospheric Pressure. In Proceedings of the Greenhouse Gas Control Technologies—6th International Conference, Kyoto, Japan, 1-4 October 2002; Gale, J., Kaya, Y., Eds.; Pergamon: Oxford, UK, 2003; pp. 155-160.

52. Tuinier, M.J.; van Sint Annaland, M.; Kramer, G.J.; Kuipers, J.A.M. Cryogenic $\mathrm{CO}_{2}$ capture using dynamically operated packed beds. Chem. Eng. Sci. 2010, 65, 114-119. [CrossRef]

53. Nanda, S.; Reddy, S.N.; Mitra, S.K.; Kozinski, J.A. The progressive routes for carbon capture and sequestration. Energy Sci. Eng. 2016, 4, 99-122. [CrossRef]

54. Hart, A.; Gnanendran, N. Cryogenic $\mathrm{CO}_{2}$ capture in natural gas. Energy Procedia 2009, 1, 697-706. [CrossRef]

55. Kenarsari, S.D.; Yang, D.; Jiang, G.; Zhang, S.; Wang, J.; Russell, A.G.; Wei, Q.; Fan, M. Review of recent advances in carbon dioxide separation and capture. RSC Adv. 2013, 3, 22739-22773. [CrossRef]

56. Klinthong, W.; Yang, Y.-H.; Huang, C.-H.; Tan, C.-S. A Review: Microalgae and Their Applications in $\mathrm{CO}_{2}$ Capture and Renewable Energy. Aerosol Air Qual. Res. 2015, 15, 712-742.

57. Yang, M.; Song, Y.; Jiang, L.; Zhao, Y.; Ruan, X.; Zhang, Y.; Wang, S. Hydrate-based technology for $\mathrm{CO}_{2}$ capture from fossil fuel power plants. Appl. Energy 2014, 116, 26-40. [CrossRef]

58. Zheng, J.; Chong, Z.R.; Qureshi, M.F.; Linga, P. Carbon Dioxide Sequestration via Gas Hydrates: A Potential Pathway toward Decarbonization. Energy Fuels 2020. [CrossRef]

59. Matsuo, S.; Umeda, H.; Takeya, S.; Fujita, T.A. Feasibility Study on Hydrate-Based Technology for Transporting $\mathrm{CO}_{2}$ from Industrial to Agricultural Areas. Energies 2017, 10, 728. [CrossRef]

60. International Energy Agency, CCUS in Clean Energy Transitions. Available online: https://www.iea.org/reports/ccus-in-cleanenergy-transitions/a-new-era-for-ccus (accessed on 18 March 2021).

61. Svante. Capturing Carbon Economically, Today. Available online: https://svanteinc.com/carbon-capture-technology / (accessed on 18 March 2021).

62. Air Products. Carbon Capture. Available online: https://www.airproducts.com/company/innovation/carbon-capture\#/ (accessed on 18 March 2021).

63. Global CCS Institute. Facilities Database. Available online: https://co2re.co/FacilityData (accessed on 4 August 2020). 
64. Townsend, A.; Gillespie, A. Scalling Up the CCS Market to Deliver Net-Zero Emissions; Global CCS Institute: Docklands, Australia, 2020; Available online: https:/ /www.globalccsinstitute.com/wp-content/uploads/2020/04/Thought-Leadership-Scaling-upthe-CCS-Market-to-Deliver-Net-Zero-Emissions-Digital-6.pdf (accessed on 18 March 2021).

65. Budinis, S.; Krevor, S.; Dowell, N.M.; Brandon, N.; Hawkes, A. An assessment of CCS costs, barriers and potential. Energy Strategy Rev. 2018, 22, 61-81. [CrossRef]

66. Karayannis, V.; Charalampides, G.; Lakioti, E. Socio-economic Aspects of CCS Technologies. Procedia Econ. Financ. 2014, 14, 295-302. [CrossRef]

67. Stigson, P.; Hansson, A.; Lind, M. Obstacles for CCS deployment: An analysis of discrepancies of perceptions. Mitig. Adapt. Strateg. Glob. Chang. 2012, 17, 601-619. [CrossRef]

68. Ranjan, M.; Herzog, H.J. Feasibility of air capture. Energy Procedia 2011, 4, 2869-2876. [CrossRef]

69. Gutknecht, V. Awesome Extractors. Available online: https://mag.ebmpapst.com/en/industries/refrigeration-ventilation/ awesome-extractors_12472/(accessed on 6 August 2020).

70. Sandalow, D.; Friedmann, J.; McCormick, C.; McCoy, S. Direct Air Capture of Carbon Dioxide. 2018. Available online: https:/ /www.globalccsinstitute.com/wp-content/uploads/2020/06/JF_ICEF_DAC_Roadmap-20181207-1.pdf (accessed on 18 March 2021).

71. Mazzotti, M.; Baciocchi, R.; Desmond, M.J.; Socolow, R.H. Direct air capture of $\mathrm{CO}_{2}$ with chemicals: Optimization of a two-loop hydroxide carbonate system using a countercurrent air-liquid contactor. Clim. Chang. 2013, 118, 119-135. [CrossRef]

72. Ocean Studies Board and National Academies of Sciences Engineering, and Medicine. Negative Emissions Technologies and Reliable Sequestration: A Research Agenda; The National Academies Press: Washington, DC, USA, 2019.

73. Sinha, A.; Realff, M.J. A parametric study of the techno-economics of direct $\mathrm{CO}_{2}$ air capture systems using solid adsorbents. AIChE J. 2019, 65, e16607. [CrossRef]

74. Keith, D.W.; Holmes, G.; St. Angelo, D.; Heidel, K. A Process for Capturing $\mathrm{CO}_{2}$ from the Atmosphere. Joule 2018, 2, 1573-1594. [CrossRef]

75. Carbon Engineering Ltd. Direct Air Capture. Available online: https://carbonengineering.com/our-technology/ (accessed on 18 March 2021).

76. Beuttler, C.; Charles, L.; Wurzbacher, J. The Role of Direct Air Capture in Mitigation of Anthropogenic Greenhouse Gas Emissions. Front. Clim. 2019, 1, 10. [CrossRef]

77. International Energy Agency. Direct Air Capture; International Energy Agency: Paris, France, 2020. Available online: https: //www.iea.org/reports/direct-air-capture (accessed on 9 April 2021).

78. Creutzig, F.; Breyer, C.; Hilaire, J.; Minx, J.; Peters, G.; Socolow, R. The mutual dependence of negative emission technologies and energy systems. Energy Environ. Sci. 2019, 12, 1805-1817. [CrossRef]

79. Fasihi, M.; Efimova, O.; Breyer, C. Techno-economic assessment of $\mathrm{CO}_{2}$ direct air capture plants. J. Clean. Prod. 2019, 224, 957-980. [CrossRef]

80. Sandalow, D.; Friedmann, J.; Aines, R.; McCormick, C.; McCoy, S.; Stolaroff, J. Industrial Heat Decarbonization Roadmap; ICEFInnovation for Coal Earth Forum: Tokyo, Japan, 2019. 